\title{
Counteracting Protein Kinase Activity in the Heart: The Multiple Roles of Protein Phosphatases
}

\author{
Silvio Weber ${ }^{1 *}$, Stefanie Meyer-Roxlau ${ }^{1}$, Michael Wagner ${ }^{1}$, Dobromir Dobrev ${ }^{2}$ and \\ Ali El-Armouche ${ }^{1 *}$ \\ ${ }^{1}$ Department of Pharmacology and Toxicology, Dresden University of Technology, Dresden, Germany, \\ ${ }^{2}$ Institute of Pharmacology, Faculty of Medicine. West German Heart and Vascular Center, Essen, Germany
}

OPEN ACCESS

Edited by:

Friederike Cuello,

University Medical Center

Hamburg-Eppendorf, Germany

Reviewed by:

Bin-Nan Wu,

Kaohsiung Medical University, Taiwan

Robert Gros,

Robarts Research Institute, Canada

${ }^{*}$ Correspondence:

Silvio Weber

silvio.weber@tu-dresden.de;

Ali El-Armouche

ali.el-armouche@tu-dresden.de

Specialty section:

This article was submitted to Cardiovascular and Smooth Muscle

Pharmacology,

a section of the journal

Frontiers in Pharmacology

Received: 24 August 2015

Accepted: 28 October 2015

Published: 13 November 2015

Citation:

Weber S, Meyer-Roxlau S, Wagner M, Dobrev D and El-Armouche A (2015)

Counteracting Protein Kinase Activity in the Heart: The Multiple Roles

of Protein Phosphatases.

Front. Pharmacol. 6:270.

doi: 10.3389/fphar.2015.00270
Decades of cardiovascular research have shown that variable and flexible levels of protein phosphorylation are necessary to maintain cardiac function. A delicate balance between phosphorylated and dephosphorylated states of proteins is guaranteed by a complex interplay of protein kinases (PKs) and phosphatases. Serine/threonine phosphatases, in particular members of the protein phosphatase (PP) family govern dephosphorylation of the majority of these cardiac proteins. Recent findings have however shown that PPs do not only dephosphorylate previously phosphorylated proteins as a passive control mechanism but are capable to actively control PK activity via different direct and indirect signaling pathways. These control mechanisms can take place on (epi-)genetic, (post-)transcriptional, and (post-)translational levels. In addition PPs themselves are targets of a plethora of proteinaceous interaction partner regulating their endogenous activity, thus adding another level of complexity and feedback control toward this system. Finally, novel approaches are underway to achieve spatiotemporal pharmacologic control of PPs which in turn can be used to fine-tune misleaded PK activity in heart disease. Taken together, this review comprehensively summarizes the major aspects of PP-mediated PK regulation and discusses the subsequent consequences of deregulated PP activity for cardiovascular diseases in depth.

Keywords: PP1, PP2A, calcineurin, PIP, protein phosphatase inhibitor-1 (I-1)

\section{INTRODUCTION}

Myriads of studies starting from the late 1930s have unequivocally shown that protein kinases (PKs) are essential for cellular homeostasis not only in the heart but in virtually any tissue of the body (Cori et al., 1939; Rapundalo, 1998; Cohen, 2002a; Harvey, 2004; Johnson, 2009; Sato et al., 2015). We have now gathered a deep understand how PKs work in the context of cardiovascular diseases (CVDs) and consequently it is anticipated that PKs may serve as the pharmacological drug target of the twenty-first century (Cohen, 2002a,b; Force et al., 2004; Belmonte and Blaxall, 2011; Roskoski, 2015). Although discovered at an equally early time point in scientific history, protein phosphatases (PPs) have received much less attention in terms of functional studies and for consideration as potential drug targets. This is somewhat astonishing as (phospho-)proteomic studies suggested that nearly one third of all protein phosphorylation events is reversible (Sefton, 2001; Olsen et al., 2006) and it seems likely that targeting phosphatases in CVDs can be similarly promising. One explanation for this observation can be certainly attributed to the difference in substrate selection between PKs and PPs (Brinkworth et al., 2003; Zhu et al., 2005; Ubersax and Ferrell, 2007; 
Roy and Cyert, 2009; Slupe et al., 2011; Li et al., 2013; Peti et al., 2013; Palmeri et al., 2014). While more than 400 available PKs often recognize decent consensus sequences in their target proteins, a far smaller number of phosphatases does not rely on specific enzyme-substrate recognition but mainly interact via so called phosphatase interacting proteins (PIPs) with their respective substrate, thus decreasing druggability enormously in comparison to PKs (Cohen, 2002c; Chatterjee and Kohn, 2013; De Munter et al., 2013; Li et al., 2013). Nevertheless recent developments have revealed exciting opportunities for the application of phosphatase-regulating drugs in CVDs and will therefore be discussed at the end of this review.

Protein phosphatases can be divided into three different subgroups, namely serine-threonine, tyrosine, and dual-specific phosphatases depending on their endogenous phosphorylation substrate (Maillet et al., 2008; Auger-Messier et al., 2013; Heijman et al., 2013; Senis, 2013). Thereby more than $98 \%$ of dephosphorylation events are carried out by serine-/threonine phosphatases and within this group $\mathrm{PP} 1,2 \mathrm{~A}$, and 2B (PP1, PP2A and PP2B, also called calcineurin) amount to $90 \%$ of all dephosphorylation activity in the heart (Cohen, 1989; MacDougall et al., 1991). As a consequence this review will focus on the latter PPs and their role as cellular opponents of the aforementioned PKs in the healthy and diseased heart. Nevertheless we would like to refer the reader to some recent excellent reviews and research publication showing the physiological and pathophysiological importance of phosphatases which are not discussed in this review (Pulido and Hooft van Huijsduijnen, 2008; Patterson et al., 2009; Senis, 2013; Lauriol et al., 2015). Before we will deeply dive into the functional role of PP1, PP2A, and PP2B and their potential as drug target in CVDs, we will shortly recapitulate the structure of these enzymes which are virtually all working as holo-enzymes as this is crucial for the understanding of the following chapters. Figure 1 shows a schematic drawing of the mouse representative PP1, PP2A, and PP2B holoenzymes known so far.

In mammals, the catalytic PP1 subunit is encoded by three separate genes (PPP1CA, PPP1CB, and PPP1CC) which seem to have distinct subcellular functions as suggested by initial studies using isoform specific knock-down and knock-out studies (Aoyama et al., 2011; Liu et al., 2015). Nevertheless there is neither detailed information available about spatiotemporal control of PP1 isoforms in the healthy or diseased heart nor insights into the molecular mechanism at this time (Luss et al., 2000). Further diversification of PP1 isoforms is achieved by alternative splicing of PPP1CA $\left(\mathrm{PP} 1 \alpha_{1-3}\right)$ and PPP1CC $\left(\mathrm{PP} 1 \gamma_{1 / 2}\right) . \mathrm{PP} 1 \gamma_{2}$ seems to be the only tissue-specific expressed PP1 (brain and testis) while all other isoforms are expressed ubiquitously (Cohen, 2002c; Ceulemans and Bollen, 2004; Korrodi-Gregorio et al., 2014). Multiple studies have suggested that there is actually no freely available PP1 within the cardiac cell but rather a competition of $>150$ regulatory subunits to form a holo-complex with the PP1 catalytic subunits. These regulatory subunits determine subcellular localization and substrate specificity of the different PP1 isoform catalytic subunits. A series of excellent reviews gives a comprehensive overview about this aspect of PP1 (Ceulemans and Bollen, 2004).

The composition of the PP2A holo-enzyme is even more complex. It can be either a heterodimer consisting of the catalytic (PP2A-C $\alpha$ or $\mathrm{C} \beta$ ) and the structural scaffold (PP2A-A $\alpha$ or A $\beta$ ) or a trimer consisting of the catalytic, the structural scaffold and another regulatory subunit (PPP2RX; Herzig and Neumann, 2000; Heijman et al., 2013). The importance of PP2a regulation becomes obvious since altered expression and activities are closely associated with heart diseases (Lei et al., 2015). Intriguingly PP1 and PP2A seem to share a couple of substrates together (Heijman et al., 2013). If this is due to compensatory mechanisms after genetic knockdown or knockout of single PP1/PP2A genes or caused by lack of specificity of the available pharmacological inhibitors has still to be determined. For further reading about the molecular mechanisms underlying PP2A regulation in the heart we would again like to recommend another set of enlightening reviews (Janssens and Goris, 2001; DeGrande et al., 2013; Lei et al., 2015).

Finally we would like to highlight PP2B (or calcineurin) as an essential cardiac PP which links $\mathrm{Ca}^{2+}$ and phosphorylationdependent signaling pathways. Initially mainly studies identified calcineurin as a regulator of $\mathrm{Ca}^{2+}$ mediated gene transcription during cardiac remodeling, but recently calcineurin was also shown to directly act as an essential enzyme for reversible cardiac protein phosphorylation, e.g., at the cardiac L-Type $\mathrm{Ca}^{2+}$-channel (Wang et al., 2014). Heart-restricted calcineurin overexpression in mice lead to cardiac remodeling, arrhythmic events and premature, sudden cardiac death (Molkentin, 2000). Again, PP2B is mainly active as a holo-enzyme consisting of one of the three different catalytic isoforms $\mathrm{CNA} \alpha, \beta$ or $\gamma$, the $\mathrm{Ca}^{2+}$-binding subunit $\left(\mathrm{CNB}_{\alpha / \beta}\right)$ and sometimes another regulatory protein, e.g., AKAP or Cain (Lim and Molkentin, 1999; Wolska, 2009; Heineke and Ritter, 2012; Wang et al., 2014).

After clarifying the functional impact and physiological importance of PPs in the heart, we will now move on to discuss which cardiac proteins are targets of reversible protein phosphorylation by PKs and PPs and how this may relate to CVD pathology.

\section{PROTEIN PHOSPHATASES COUNTERACT PROTEIN KINASE MEDIATED PROTEIN PHOSPHORYLATION IN THE HEART}

One of the hallmarks of CVDs is altered phosphorylation of cardiac proteins (Rapundalo, 1998; Luo and Anderson, 2013). Thereby most of the knowledge stems from studies of isolated cardiac myocytes, while studies about the substrates of reversible phosphorylation in cardiac fibroblasts, endothelial and smooth muscle cells are rather limited. Table 1 gives a comprehensive and compartment-sorted overview about PP1, PP2A, and PP2B substrates in cardiac cells. In this chapter we highlight some important examples of phosphatase-dependent substrate regulation in cardiac cells and visualize them additionally in Figure 2. 

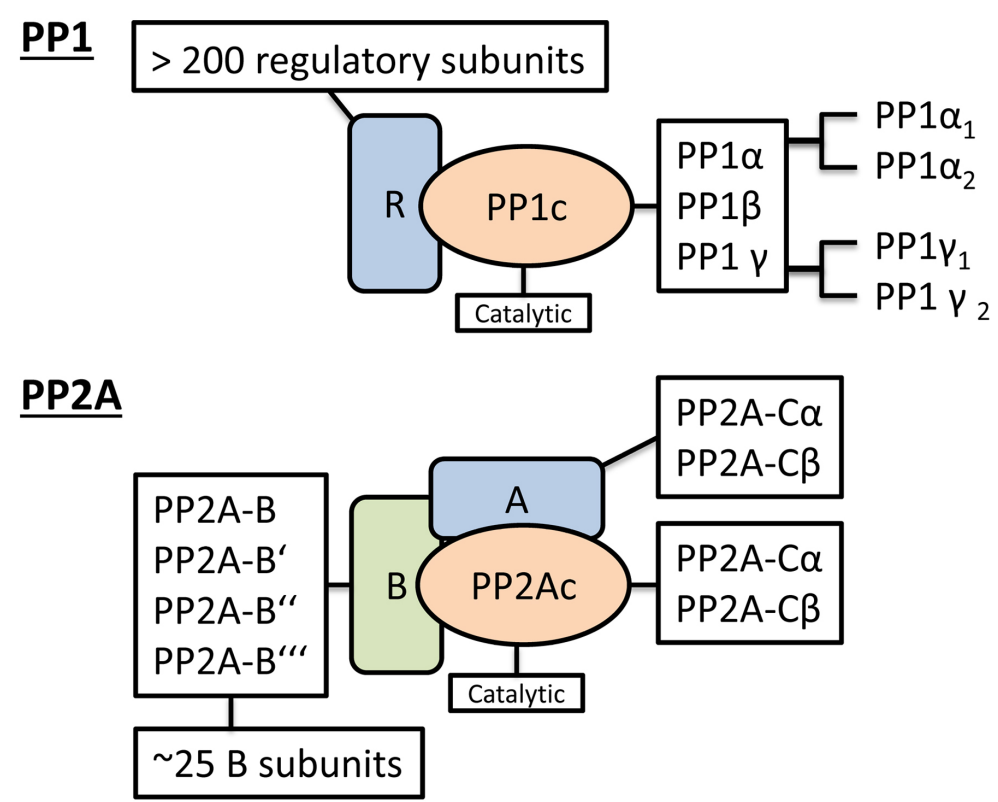

\section{PP2B (Calcineurin)}

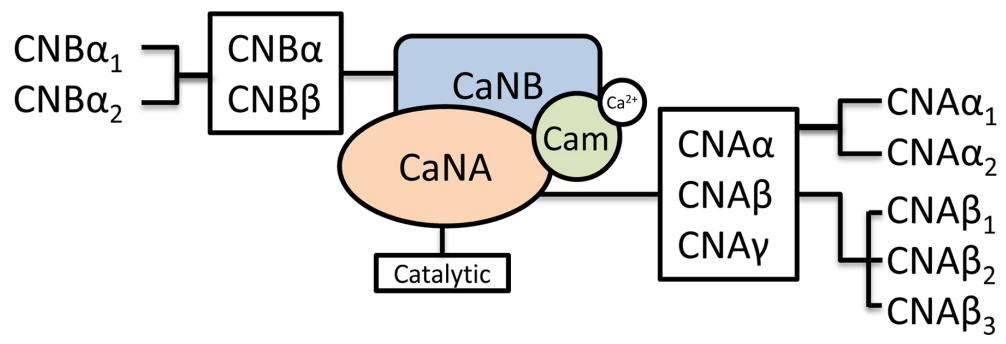

FIGURE 1 | Holoenzyme composition of protein phosphatases. The schematic drawing of the holoenzyme composition of PP1, PP2A and PP2B (Calcineurin) indicates the combinatorial complexity of the different catalytic and regulatory protein phosphatase subunits. A detailed description of the underlying nomenclature and the nature of the regulatory subunits can be found in Heijman et al. (2013).

\section{The L-Type Calcium Channel, $\mathrm{Na}^{+} / \mathrm{K}^{+}$-ATPase and Other lon Channels-Reversible Protein Phosphorylation at the Plasma Membrane}

Reversible phosphorylation has been shown for a huge subset of different ion channels and their respective subunits. While the kinases required for phosphorylation have often been identified, the exact nature and contribution of phosphatases remained enigmatic due to the aforementioned reasons. The best studied examples of reversible protein phosphorylation at the plasma membrane are therefore the L-Type calcium channel ( $\left.\mathrm{Ca}_{\mathrm{V}} 1.2\right)$ and the $\mathrm{Na}^{+} / \mathrm{K}^{+}$-ATPase dependent substrates in cardiac cells. Phosphorylation at the $\alpha$-Subunit of $\mathrm{Ca}_{V} 1.2$ takes place on multiple residues including Ser1512 and Ser1570 (CaMKII) as well as Ser1866 and Ser1928 (PKA; Chen et al., 2002; Yang et al., 2005; Lee et al., 2006; Lemke et al., 2008; Blaich et al., 2010; Minobe et al., 2014). There is still controversy which of these phosphorylation sites is the most important one for regulation of the $\mathrm{Ca}_{\mathrm{V}} 1.2$ function, but most studies hint at an essential role of Ser1928 (Yang et al., 2005; Hulme et al., 2006; Lemke et al., 2008; Xu et al., 2010). It seems as if PP1, PP2A, and even PP2B can bind to this region and regulate dephosphorylation levels in concert (Davare et al., 2000; Hall et al., 2006; Tandan et al., 2009; Shi et al., 2012). It was reported that PP1 and PP2A act directly on the phosphorylation level of $\mathrm{Ca}_{\mathrm{V}} 1.2$ and $\mathrm{PP} 2 \mathrm{~B}$ may have rather indirect effect by blocking PP1 and PP2A binding sites on the one hand and controlling Cav1.2 expression level via the CREB signaling pathway on the other hand (Tandan et al., 2009; Wang et al., 2014). Spatiotemporal control of PP2A activity at the Cav 1.2 alpha-subunit is known to be mediated via the B56 (all isoforms) or PR59 subunits, while the mechanism of regulation of PP1 is still unknown (Hall et al., 2006; Xu et al., 2010). In general, PP2Amediated dephosphorylation leads to downregulated $\mathrm{Ca}_{V} 1.2$ activity (Heijman et al., 2013). Finally pharmacological inhibition studies suggested that aforementioned PPs may play a role for dephosphorylation of basal as well as adrenoceptor induced Cav 1.2 phosphorylation, which renders them different from PKA and CaMKII, that were shown to be either more important for basal (CaMKII) or adrenoceptor induced (PKA) Cav1.2 
TABLE 1 | Targets for reversible cardiac protein phosphorylation.

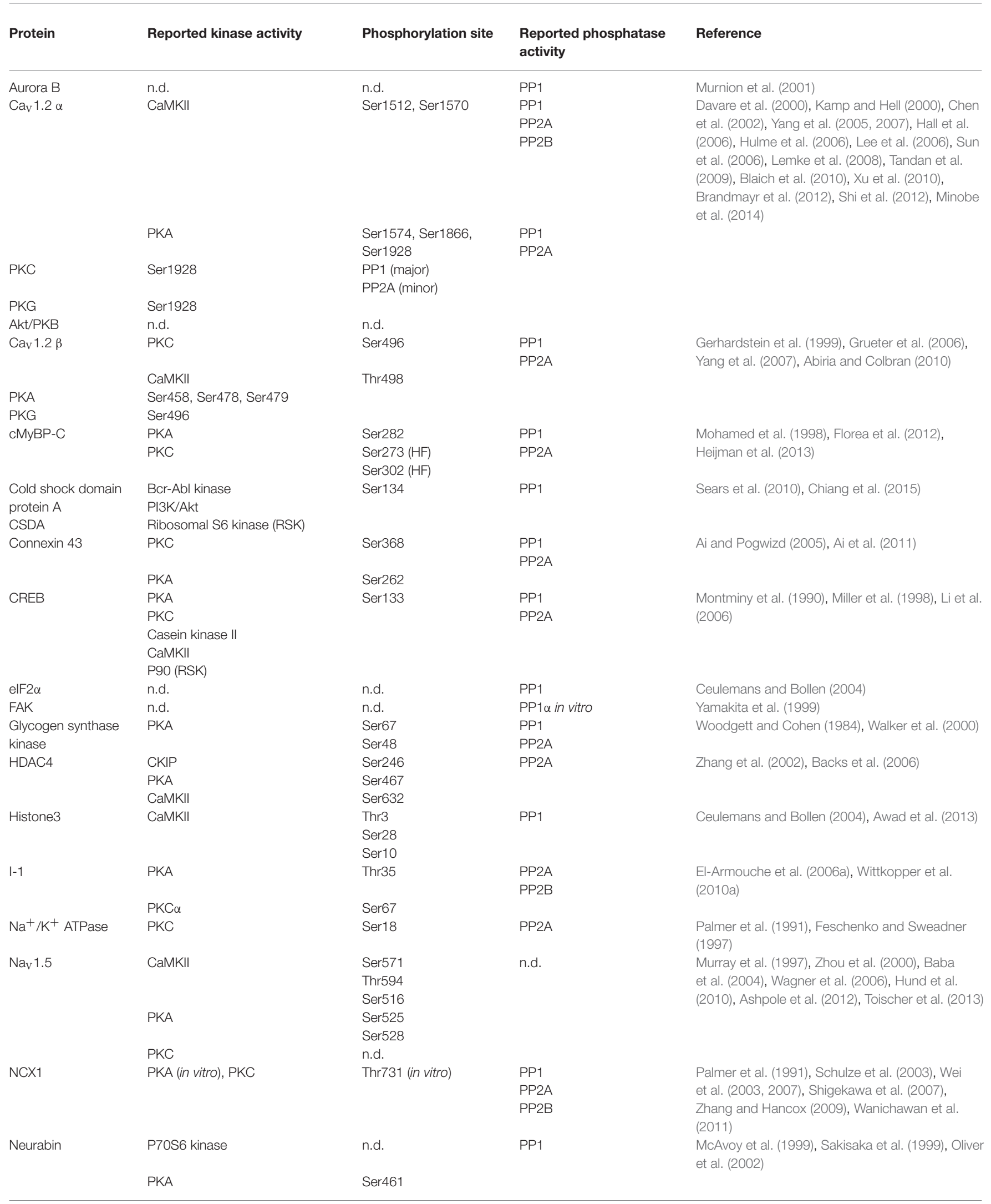

(Continued) 
TABLE 1 | Continued

\begin{tabular}{|c|c|c|c|c|}
\hline Protein & Reported kinase activity & Phosphorylation site & $\begin{array}{l}\text { Reported phosphatase } \\
\text { activity }\end{array}$ & Reference \\
\hline NFATs & $\begin{array}{l}\text { PKA } \\
\text { GSK3 } \beta \\
\text { DYRK1/2 } \\
\text { CK1 } \\
\text { MEKK1 } \\
\text { JNK } \\
\text { P38MAPK }\end{array}$ & multiple & PP2B & $\begin{array}{l}\text { Beals et al. (1997), Chow et al. (1997, 2000), Zhu } \\
\text { et al. (1998), Chow and Davis (2000), Gomez del } \\
\text { Arco et al. (2000), Sheridan et al. (2002), Yang } \\
\text { et al. (2002), Okamura et al. (2004), Gwack et al. } \\
\text { (2006) }\end{array}$ \\
\hline \multirow[t]{2}{*}{ PDE4D3 } & PKA & $\begin{array}{l}\text { Ser13 } \\
\text { Ser54 }\end{array}$ & $\begin{array}{l}\text { PP1 } \\
\text { PP2A }\end{array}$ & $\begin{array}{l}\text { Egloff et al. (1997), Carlisle Michel et al. (2004), } \\
\text { Dodge-Kafka et al. (2006), De Arcangelis et al. } \\
\text { (2008) }\end{array}$ \\
\hline & ERK5 & Ser579 & & \\
\hline PDE5A & n.d. & n.d. & PP1 & Chiang et al. (2015) \\
\hline Phospholemman & $\begin{array}{l}\text { PKA } \\
\text { PKC }\end{array}$ & $\begin{array}{l}\text { Ser68 } \\
\text { Ser63 } \\
\text { Ser68 }\end{array}$ & PP1 & Palmer et al. (1991), El-Armouche et al. (2011) \\
\hline PLB & PKA & Ser16 & $\begin{array}{l}\text { PP1 } \\
\text { PP2A }\end{array}$ & $\begin{array}{l}\text { MacDougall et al. (1991), Luo et al. (1994), } \\
\text { Jackson and Colyer (1996), Chu and Kranias } \\
\text { (2002) }\end{array}$ \\
\hline & CaMKII & Ser17 & & \\
\hline PMCA & $\begin{array}{l}\mathrm{PKA} \\
\mathrm{PKC}\end{array}$ & n.d. & $\begin{array}{l}\text { PP1 } \\
\text { PP2A }\end{array}$ & $\begin{array}{l}\text { Zylinska et al. (1998), Zylinska and Soszynski } \\
\text { (2000) }\end{array}$ \\
\hline P70S6 Kinase & n.d. & n.d. & $\begin{array}{l}\text { PP1 } \\
\text { PP2A }\end{array}$ & Bettoun et al. (2002) \\
\hline $\begin{array}{l}\text { Retinoblastoma } \\
\text { protein (Rb) }\end{array}$ & CDK & Thr320 & PP1 & Liu et al. (1999), Ceulemans and Bollen (2004) \\
\hline RyR2 & PKA & $\begin{array}{l}\text { Ser2808 } \\
\text { Ser2030 }\end{array}$ & $\begin{array}{l}\text { PP1 } \\
\text { PP2A } \\
\text { PP2B }\end{array}$ & $\begin{array}{l}\text { Marx et al. (2000), Pare et al. (2005), Xiao et al. } \\
\text { (2005, 2006), Meng et al. (2007), Liu et al. (2011, } \\
\text { 2014), Zhang et al. (2012) }\end{array}$ \\
\hline & CaMKII & Ser2814 & & \\
\hline SERCA2a & CaMKII & $\begin{array}{l}\text { Ser38 } \\
\text { (Ser167, Ser531 } \rightarrow \text { in } \\
\text { vitro) }\end{array}$ & n.d. & Brandl et al. (1986), Narayanan and Xu (1997) \\
\hline SF2/ASF & PKA & n.d. & PP1 & Gu et al. (2011), Huang et al. (2014) \\
\hline Tn-inhibitor (Tnl) & PKA & $\begin{array}{l}\text { Ser23 } \\
\text { Ser24 }\end{array}$ & $\begin{array}{l}\text { PP1 } \\
\text { PP2A }\end{array}$ & Cole and Perry (1975) \\
\hline $\begin{array}{l}\text { T-type calcium } \\
\text { channel (Cav3.2) }\end{array}$ & PKA & $\begin{array}{l}\text { Ser1107 } \\
\text { Thr2214 } \\
\text { Ser1144 }\end{array}$ & n.d. & Chemin et al. (2007), Hu et al. (2009) \\
\hline Vitamin D receptor & $\begin{array}{l}\text { P70S6 } \\
\text { Pl-3 kinase } \\
\text { B/Akt }\end{array}$ & n.d. & $\begin{array}{l}\text { PP1 } \\
\text { PP2A }\end{array}$ & Bettoun et al. (2002) \\
\hline Yotiao/KCNQ1 & PKA & Ser27 & PP1 & $\begin{array}{l}\text { Westphal et al. (1999), Marx et al. (2002), } \\
\text { Terrenoire et al. (2009) }\end{array}$ \\
\hline
\end{tabular}

This table lists currently known substrates, which PK-mediated phosphorylation is counteracted by PP1, PP2A, or/and PP2B.

phosphorylation (Brandmayr et al., 2012). As tight control of $\mathrm{Ca}_{V} 1.2$ activity during EC-coupling is essential and deregulated $\mathrm{Ca}_{V} 1.2$ function has been shown in a multitude of different CVDs, e.g., hypertension, cardiac arrhythmia and heart failure, specific targeting of $\mathrm{PP}-\mathrm{Ca}_{\mathrm{V}} 1.2$ interactions might be a versatile drug targeting in the future (Splawski et al., 2004; Tang et al., 2008; Domes et al., 2011; Hong et al., 2012; Tajada et al., 2013).

Another important target for reversible dephosphorylation at the plasma membrane is the $\mathrm{Na}^{+} / \mathrm{K}^{+}$-ATPase, which can be either indirectly regulated via PP1-mediated dephosphorylation of the $\mathrm{Na}^{+} \mathrm{K}^{+}$-ATPase subunit phospholemman at position Ser68 or by direct recruitment of PP2A via its subunit PP2A-B56 and subsequent dephosphorylation at position Ser18 (Neumann et al., 1999; El-Armouche et al., 2006a; Bhasin et al., 2007). Interestingly binding of PP2A to $\mathrm{Na}^{+} \mathrm{K}^{+}$-ATPase diminishes binding of arrestin, thus increasing membrane localization of the pump and thereby actively modulating function of the $\mathrm{Na}^{+} \mathrm{K}^{+}$. ATPase (Kimura et al., 2011). The above mentioned studies also provided an important breakthrough in better understanding the role of reversible $\mathrm{Na}^{+} \mathrm{K}^{+}$-ATPase phosphorylation for CVD development. The described mechanism is markedly perturbed in failing hearts favoring phospholemman dephosphorylation and $\mathrm{Na}^{+} \mathrm{K}^{+}$-ATPase deactivation and thus may contribute to maladaptive hypertrophy and arrhythmogenesis via chronically increased intracellular $\mathrm{Na}^{+}$and $\mathrm{Ca}^{2+}$ concentrations (Neumann et al., 1999; Schwinger et al., 2003; Cheung et al., 2010; ElArmouche et al., 2011). 


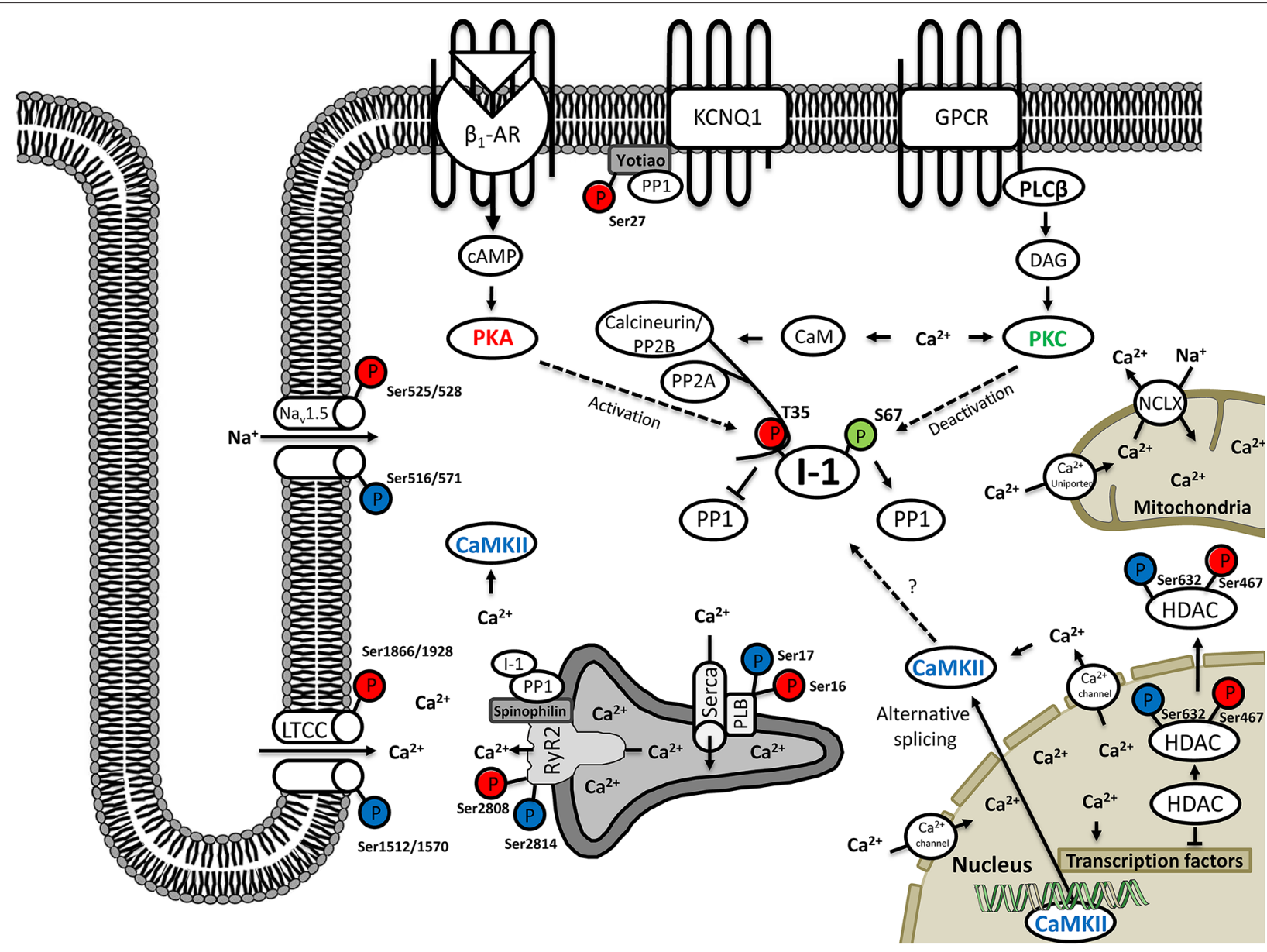

FIGURE 2 | Protein phosphatase inhibitor-1 (I-1) fulfills a nodal role during reversible protein phosphorylation in cardiomyocytes. On the primary level $\mathrm{I}-1$ is mainly regulated by the complex interplay of protein kinases: PKA (red color), PKC (green color) and indirectly also CaMKII (blue color) vs. protein phosphatases 2A and 2B. While PKA (and CaMKII) have activating function, PKC, PP2A, and PP2B are limiting I-1 activity. On the secondary level, CaMKII and PP2B and thus subsequently also I-1, are regulated by intracellular calcium levels, which are mediated by a complex flux balance from internal $\mathrm{Ca}^{2+}$ stores of the sarcoplasmic reticulum, the mitochondria and the nucleus as well as $\mathrm{Ca}^{2+}$ influx from extracellular space. In turn I-1 is mainly acting on protein phosphatase 1 which dephosphorylates a multitude of functional proteins of the cardiomyocyte (see Table 1) and can act on different cellular functions including contraction, ion flux/currents, transcription and/or splicing, accordingly.

Finally there are some reports indicating reversible phosphorylation of Sodium and Potassium Channels, e.g., $\mathrm{Na}_{\mathrm{V}} 1.5$ and KCNQ1, that are essential for membrane excitation (Murray et al., 1997; Terrenoire et al., 2009; Marionneau et al., 2012; Toischer et al., 2013). In case of Nav1.5 many different phosphorylation sites have been described, with a priority of PKA-mediated phosphorylation in peak $\mathrm{I}_{\mathrm{Na}}$ and CamKIImediated phosphorylation during late $\mathrm{I}_{\mathrm{Na}}$ (Baba et al., 2004; Bers and Herren, 2012; Marionneau et al., 2012). To our knowledge there is just one report about a protein tyrosine phosphatase (PTP1) working as a counteracting phosphatase after PKA or CamKII-mediated $\mathrm{Na}_{V} 1.5$ phosphorylation, so additional studies to identify putative PP-mediated $\mathrm{Na}_{\mathrm{V}} 1.5$ dephosphorylation might be helpful (Jespersen et al., 2006). Even less is known with respect to reversible KCNQ1 phosphorylation. Initial studies show that PKA can mediated phosphorylation of KCNQ1 at position Ser27 at its C-terminal tail, which may by counteracted by PP1 and regulated by the accessory protein Yotiao (Marx et al., 2002; Nicolas et al., 2008). However, more studies are needed to understand the functional implication of reversible phosphorylation in this macromolecular protein complex at the plasma membrane are needed.

\section{Phospholamban and the Ryanodine Receptor-Reversible Protein Phosphorylation at the Sarcoplasmic Reticulum}

Disturbed $\mathrm{Ca}^{2+}$-handling is coming along with most CVDs and numerous studies using genetically modified or pharmacologically treated animals have revealed the importance of tight spatiotemporal control of the two sarcoplasmic reticulum (SR) residing proteins ryanodine receptor type-2 (RyR2) and phospholamban (PLB) in this context. Consequently, tremendous 
efforts have been undertaken to identify the exact contribution of kinases and phosphatases toward deregulated phosphorylation of the latter proteins. While the large intracellular C-terminus of RyR2 contains multiple putative phosphorylation sites, only three of them have been extensively studied until today. Although still under debate, it seems as if Ser2808 and Ser2030 are the major PKA and Ser2814 is the major CaMKII phosphorylated site (Marx et al., 2000; Marks et al., 2002; El-Armouche and Eschenhagen, 2009). Dephosphorylation can be carried out by either PP1, which is targeted by spinophilin and/or PP2A which is targeted by its subunit PR130 to the multiprotein RyR2 holo-complex (Marx et al., 2001; Reiken et al., 2003; Chiang et al., 2014). There are no reports about calcineurin mediated RyR2 dephosphorylation but it has been suggested that deregulated RyR2 activity can modulate calcineurin expression in turn, thus serving as a potential hub for feedback inhibition of reversible cardiac protein phosphorylation (Zou et al., 2011).

In contrast PP1 is the major dephosphorylating enzyme of PLB, which critically modulates the activity of the SR $\mathrm{Ca}^{2+}$. ATPase (SERCA2a). A small contribution has been also shown for PP2A, but this relates to less than $30 \%$ of the dephosphorylation events at positions Ser16 (PKA-controlled) and Thr17 (CaMKIIcontrolled; MacDougall et al., 1991; Jackson and Colyer, 1996; Chu and Kranias, 2002; Aye et al., 2012). Increased targeting of PP1 to PLB is achieved by $\mathrm{R}_{\mathrm{GL}}$ or HSP20, which leads to reduced SERCA2a $\mathrm{Ca}^{2+}$ uptake and thus attenuated $\beta$-AR stimulationinduced lusitropy (Berrebi-Bertrand et al., 1998).

\section{Troponin-I and cMyBP-C-Reversible Protein Phosphorylation at the Myofilaments}

The most important consequences of the elevated systolic $\mathrm{Ca}^{2+}$ level is the activation of the contractile apparatus, which is again dependent on the amount of phosphorylation of the associated contractile proteins, e.g., the cardiac myosin-binding protein- $\mathrm{C}$ (cMyBP-C) or the Inhibitor of the Troponin complex, TroponinI (Barefield and Sadayappan, 2010). For the latter, PP1 seems to preferentially dephosphorylate Ser23 and Ser24 on TnI, while the exact substrate of PP2A is yet undetermined (Jideama et al., 2006). Nevertheless it could be detected that targeting of PP2A is B56 $\alpha$ dependent and $\beta$-AR stimulation seems to be able to dissociate this localized interaction (Yin et al., 2010).

Phosphoproteomic studies revealed a number of putative phosphorylation sites also for cMyBP-C (Solaro and Kobayashi, 2011). Interestingly reduced phosphorylation at position Ser282 coincides with increased PP1 and PP2A activity in patients with atrial fibrillation (El-Armouche et al., 2006b). Similar results were received in end-stage heart failure, however here phosphorylation was also diminished at positions Ser273 and Ser302 (El-Armouche et al., 2007b; Sumandea and Steinberg, 2011).

\section{I-1 and PDE4D3-Reversible Protein Phosphorylation in the Cytoplasm}

An excellent showcase for the description of a typical substrate for reversible phosphorylation of a cardiac protein represents the
PP1-specific inhibitor of protein phosphatase-I (I-1). I-1 fulfills the function as a central signaling hub in feedback control of phosphatase activity and is thus topic of a number of reviews itself (Nicolaou et al., 2009; Wittkopper et al., 2010a, 2011). I- 1 activity depends on PKA-dependent Thr35 phosphorylation, which seems to be mediated via AKAP18 (Endo et al., 1996; Singh et al., 2011). During $\beta$-AR stimulation, PKA-controlled I- 1 activation and subsequent PP1 inhibition form a positive feed-back loop amplifying the phosphorylation of substrates like PLB, RyR2, and phospholemman (Carr et al., 2002; ElArmouche et al., 2003). Dephosphorylation of I-1 at position Thr35 is carried out by PP2A and PP2B, thus creating a crosstalk between the different phosphatases as well as between PKA and $\mathrm{Ca}^{2+}$-related second-messenger systems (via PP2B mediated dephosphorylation of I-1; El-Armouche et al., 2006a). Moreover, I-1 is also phosphorylated by PKC $\alpha$ on Ser67, this time resulting in reduced I-1 activity and decreased PLB phosphorylation. Conversely, the Ser67Ala substitution, preventing inactivation, increases PLB phosphorylation (Huang and Paudel, 2000; Braz et al., 2004). Figure 1 gives a schematic overview about the nodal role of I-1 during reversible cardiac protein phosphorylation.

Much less is known about reversible phosphorylation of phosphodiesterases, another important players of the adrenergic response. PP2A could be shown as a negative regulator of PDE4D3 activity in a complex with mAKAP, RyR2 and PKA (Carlisle Michel et al., 2004; Dodge-Kafka et al., 2006; De Arcangelis et al., 2008). In this case PP2A activity is itself controlled by PP2B (Dodge-Kafka et al., 2010). Further studies will be needed to elucidate the contribution of reversible phosphorylation toward function of cardiac PDEs, as malfunction of this enzymes can be beneficial or detrimental in multiple CVDs.

\section{Histone 3 and HDAC4-Reversible Protein Phosphorylation in the Nucleus}

Several studies have implicated localization and activity of phosphatases in different compartment of the nucleus including chromatin bound fractions (Bollen and Beullens, 2002; Moorhead et al., 2007). There is extensive knowledge about the counteracting role of PPs against PKs during different phases of the cell cycle in non-cardiac cells (Ceulemans and Bollen, 2004; Novak et al., 2010; Jeong and Yang, 2013). As adult cardiac myocytes are mainly non-dividing cells, phosphatase targets may be different and up to this point there are only sparse reports about nuclear phosphatase targets in this regard (von Holtey et al., 1996; Heineke and Ritter, 2012). An exception hereof is histone deacetylase 4 (HDAC4), which phosphorylation status was well studied. While CKIP and CaMKII seem to be the main kinases phosphorylating Ser246, and Ser632, PP2A was identified as a major phosphatase to control HDAC4 phosphorylation status and subsequent subcellular localization, thus modulating HDAC4 activity (Paroni et al., 2008; Ling et al., 2012; Liu and Schneider, 2013; Kreusser and Backs, 2014). Knockdown experiments of PP1 did not reveal a significant contribution toward HDAC4 dephosphorylation. This might however be different for another important phosphatase substrate of the nucleus, which is histone 3 (H3). Phosphorylation of $\mathrm{H} 3$ occurs at multiple positions, including Ser10 and Ser28 (Awad et al., 2013; Korrodi-Gregorio 
et al., 2014). PP1 was reported to significantly contribute toward dephosphorylation of at least Ser10 in non-cardiac cells rendering it a potential target also in cardiac myocytes (Awad et al., 2013). In summary PPs may act as important and rapid modifiers of the epigenetic code and predispose DNA and protein sequences for subsequent methylation-a concept that is also known as the methyl-phospho-switch hypothesis (Chen et al., 2008; Sawicka and Seiser, 2014).

\section{Nuclear Factors of Activated T-Cells (NFATs)-Regulation of Transcription by $\mathrm{Ca}^{2+}$-dependent Dephosphorylation}

Nuclear factors of activated T-cells (NFATs) are a family of transcription factors in which the nuclear localization signals (NLS) are masked by multiple phosphorylations in their serinerich domains. Upon activation of PP2B by $\mathrm{Ca}^{2+} /$ calmodulin, they are dephosphorylated, leading to their nuclear translocation, initiation of transcription and induction of cardiac hypertrophy as well as electrical remodeling (Heineke and Molkentin, 2006; Heineke and Ritter, 2012). A potential role in cardiac hypertrophy has been shown for NFATc2, NFATc3, and NFATc4. A number of PKs have been inflicted in cardiac NFAT phosphorylation, among them PKA, GSK3 $\beta$, DYRK1/2, CK1, MEKK1, JNK and P38MAPK, and some isoform specificity is present. Importantly, PKA and DYRK1/2 can act as priming kinases, enabling other kinases to access the NFAT phosphorylation sites (Pan et al., 2013). The importance of PP2B/NFAT signaling in cardiac hypertrophy was first recognized in 1998, when Molkentin et al. (1998) demonstrated that overexpression of activated PP2B of NFATc4 lead to cardiac hypertrophy. Later it became clear that NFATc3 as well as c4, but not c2 are necessary for cardiac hypertrophy in multiple models (Wilkins et al., 2004; Bourajjaj et al., 2008). Moreover, PP2B/NFAT signaling plays an important role in shaping physiological cardiac repolarization (Rossow et al., 2006) as well as in the generation of an arrhythmogenic substrate in heart failure (Rossow et al., 2004). Since cardiomyocytes dramatically increase their intracellular $\mathrm{Ca}^{2+}$ concentration during each heartbeat, an important problem to be solved is the question whether the "contractile $\mathrm{Ca}^{2+}$ " released by LTCC and RyR2 or a different pool of $\mathrm{Ca}^{2}$ regulated by LTCC and/or canonical transient receptor potential channels (TRPC1, 3 or 6) activate PP2B in CVD (Rossow et al., 2004).

\section{Connexin 43 and SAP97-Reversible Protein Phosphorylation at Cell-Cell Contacts}

Cardiac electrical excitation is mainly conducted from cell to cell by connexins. In heart especially connexins 43 and 45 fulfill an important function for conduction and increased phosphatase activity of either PP1 or PP2A was shown to induce conduction slowing possibly due to influence on protein stability and nearby channel activation (Jeyaraman et al., 2003; Ai and Pogwizd, 2005; Ai et al., 2011). Decreased connexin expression and phosphorylation was recently identified as a novel inducer of arrhythmic events (Delmar and Makita, 2012; Remo et al., 2012). Another important protein involved in such cell-cell contacts is synapse-associated protein 97 (SAP97). Numerous studies in brain have suggested CaMKII dependent phosphorylation and PP2B-mediated dephosphorylation of this scaffolding protein (Nikandrova et al., 2010). While SAP97 is also expressed in heart and initial studies in mice have revealed potential impact on potassium channel function and thereby action potential duration, there is a lack of knowledge regarding reversible SAP97 phosphorylation in the heart.

\section{Glycogen Synthase and Phosphorylase-Reversible Protein Phosphorylation During Cardiac Metabolism}

Although being the first PP substrates studied in terms of regulation and mechanism, the knowledge about functional impact of phosphatases on proteins of the glycogen metabolism has been underestimated for cardiac function a long time. However, recent milestone publications have led to a revival of the study of metabolic pathways and their contribution toward CVDs (Kolwicz et al., 2013; Chouchani et al., 2014; Mirtschink et al., 2015). The most important substrates of PP1 and PP2A are glycogen synthase, glycogen phosphorylase and to a lesser extent, phosphorylase kinase (Ceulemans and Bollen, 2004). PP1 and PP2A-mediated dephosphorylation of the rate-limiting enzymes of glycogen metabolism results in the storage of glycogen, in accordance with the proposed function of PP1 as an energy conserving enzyme (Ceulemans and Bollen, 2004). Future studies will be necessary to understand the exact contribution of the different phosphatases in cardiac cells in this process and to translate these findings for the understanding of pathophysiological processes. In this regard it will also be essential to check reversible phosphorylation in other metabolic pathways, e.g., lipid, amino acid, and nucleotide metabolism.

While this chapter indicated the widespread target portfolio of PPs in the heart, the molecular regulation of PPs themselves is at least equally important for cardiac physiology and manifestation of CVDs. Therefore we are going to review the multiple checkpoints of PP regulation in the heart in the light of PPdependent $\mathrm{PK}$ activity regulation.

\section{REGULATING THE REGULATORS: MOLECULAR CONTROL OF PROTEIN PHOSPHATASE ACTIVITY IN THE HEALTHY AND DISEASED HEART}

PPs themselves can be regulated at multiple checkpoints. We will first discuss and highlight some of this regulative mechanisms and subsequently summarize the consequences of deregulated phosphatase activity in CVDs.

The perhaps most obvious but still not really well studied mechanism of transcriptional control is the expression of different isoforms of the catalytic subunits of PP1, PP2A, and PP2B (Cohen, 2002c; Korrodi-Gregorio et al., 2014). Especially for PP1, isoform analysis in non-cardiac cells has shown difference in subcellular distribution of catalytic isoforms and response toward cellular stressors like hypoxia and/or apoptosis (Wang 
et al., 2001; Comerford et al., 2006; Iacobazzi et al., 2015). The most obvious but however not really well studied mechanism of transcriptional control is the expression of different isoforms of the catalytic subunits of PP1, PP2A, and PP2B (Herzig and Neumann, 2000; Felkin et al., 2011; DeGrande et al., 2013; Korrodi-Gregorio et al., 2014). Especially for PP1, isoform analysis in non-cardiac cells has shown difference in subcellular distribution of catalytic isoforms and response toward cellular stressors like hypoxia and/or apoptosis (Ceulemans and Bollen, 2004; Trinkle-Mulcahy et al., 2006; Djouder et al., 2007; Iacobazzi et al., 2015). Mutants of different PP1 isoforms in Drosophila or mice give rise to apparently different phenotypes (Raghavan et al., 2000; Kirchner et al., 2007). For cardiac myocytes there is yet very limited evidence that isoform-specific distribution of PP catalytic subunits underlies functional implication during CVDs, thus awaiting further examination in suitable cellular or animal models. So far preliminary reports suggest predominant expression of PP1 $\alpha$ in myofibrillar, PP1 $\beta$ in longitudinal SR and PP1 $\gamma$ in the junctional SR fraction under basal conditions (Aoyama et al., 2011). However, the small number of PP1c isoforms, their near $90 \%$ amino-acid sequence identity and their broad and similar substrate specificities in vitro support the current hypothesis that it is predominantly the regulatory subunits with which PP1c interacts that controls the specificity and enormous diversity of PP1 function. To our knowledge there is only one report about isoform specific distribution of PP2A or PP2B catalytic subunits in cardiac cells until today enforcing the importance of regulatory subunits for substrate specificity and subcellular distribution also for the two latter phosphatases (DeGrande et al., 2013). In addition there is some limited knowledge about the characteristic of the calcineurin promoter, while we are not aware of any reports about PP1 or PP2A promoter analysis in cardiac cells leaving a huge unexplored research field of PP activity regulation (Oka et al., 2005). Finally some sparse studies hint at epigenetic regulation mechanisms of, e.g., PP2A expression control but again specific and detailed mechanistic studies in cardiac cells are missing (Keen et al., 2004). Thus although deregulated expression of PPs have been reported during a variety of different CVDs, and the underlying mechanistic nature has not been studied in detail yet.

An interesting opportunity of post-transcriptional PP activity control is conducted via regulated expression of microRNAs (miRs). However, most of the known examples in the heart have revealed control of $\mathrm{PP} 1, \mathrm{PP} 2 \mathrm{~A}$, and $\mathrm{PP} 2 \mathrm{~B}$ regulatory subunit rather than catalytic subunit expression by miRs so far. Prominent examples are, e.g., miR-1 and miR-133 control of RyR2/PP2A mediated arrhythmogenesis, miR-34-a control of PPP1R10 during cardiac aging and contraction, as well as miR-212/132 control of calcineurin activity during cardiac hypertrophy (Belevych et al., 2011; Ucar et al., 2012; Boon et al., 2013). It is anticipated that miR-mediated control of PP catalytic and regulatory subunits may serve as a novel attractive and highly specific pharmacological target among CVDs.

The most intensive studied way of PP activity control is, however, post-translational PP activity control, mediated either by a regulatory or an inhibitory subunit. Recent studies have suggested that the number of PIPs is bigger than the number of PP, leading to a situation of competition between the different regulatory and inhibitory subunits for the catalytic subunits of PPs (Ceulemans and Bollen, 2004). Genetic studies in transgenic mice with knock-out or overexpression of PP regulatory subunits have enforced our understanding about this process (Heijman et al., 2013). While there are, e.g., already more than 150 known regulatory subunits for $\mathrm{PP} 1$, we have decided to focus on two complex examples of $\mathrm{PP}$ activity regulation that may serve a prototype for PP regulation and inhibition, namely I-1 and spinophilin. For a comprehensive overview we would like to recommend some excellent reviews dedicated to posttranslational PP activity control (Cohen, 2002c; Redden and Dodge-Kafka, 2011).

\section{Protein Phosphatase Inhibitor-1 (I-1)}

One of the best studied examples of PP-inhibitory subunits in the heart is the I-1. Originally identified in rabbit skeletal muscle, it's expression has now been verified in nearly every tissue with highest expression in skeletal muscle, adipocytes, kidney and liver and brain (Huang and Glinsmann, 1976; Hemmings et al., 1992; Aleem et al., 2001). Interestingly I-1 can only be found in vertebrates and may therefore represent rather recent addition of the fine-tuning interplay between PKA and PP1 from an evolutionary view (Ceulemans and Bollen, 2004). I-1 is one of the few thermostable proteins and cannot be precipitated by $1 \%$ trichloroacetic acid (Aitken and Cohen, 1982; El-Armouche et al., 2004; Wittkopper et al., 2011). Although being relatively small and without any transmembrane domains, the crystal structure of I-1 could not be elucidated until recently (Huang et al., 2010). As the exact activation and inhibition mechanism of I- 1 has been already been described before in this review we will know focus on the consequence of deregulated I-1 expression on PP activity and vice versa for different CVDs.

The first example comes from failing human myocardium, which showed hyperactive PP1 (Neumann et al., 1997; Huang et al., 1999; Schwoerer et al., 2008). It was tempting to speculate that I-1 might be dysregulated in heart failure and in fact I-1 mRNA and total I-1 protein amount were reduced by $60 \%$, and its PKA-dependent phosphorylation level even by $80 \%$ (El-Armouche et al., 2003, 2004). The reason of decreased I-1 phosphorylation possibly reflects desensitization of $\beta$-AR signaling with decreased cAMP levels and PKA activation in the failing myocardium. Additionally an increase in calcineurin activity, especially in settings of elevated diastolic $\mathrm{Ca}^{2+}$ levels, may contribute to the decrease in I-1 phosphorylation described above (Lim and Molkentin, 1999). Finally I-1 protein expression was also markedly downregulated in an experimental dog model of heart failure arguing for a central role of I-1 mediated PP1 activity control during heart failure (Gupta et al., 2003; El-Armouche et al., 2007a). All these data suggest that I-1 downregulation may be part of the desensitization process taking place among the irregular $\beta$-adrenergic signal transduction pathway in failing hearts. A hypothesis that could in part be validated by studies using rats with chronic isoprenaline treatment showing decreased I-1 expression and activation levels as well (El-Armouche et al., 2007a). Knock-out of I-1 in mice in two different studies 
led to either none or a subtle decrease in basal contractile parameters and a significantly blunted $\beta$-adrenergic response (Carr et al., 2002; El-Armouche et al., 2008). Isolated atria from I-1 deleted mice showed normal isometric force under basal and maximally stimulated conditions but a rightward shift of the concentration-response curve of isoprenaline (Carr et al., 2002). Importantly, neither the $\beta$-AR density nor the $\mathrm{PP} 1$ protein levels differed from wild type littermates, indicating no obvious major compensatory changes in the I-1 KO hearts. Finally, germline deletion of I-1 did not result in apparent heart disease and did not negatively affect life expectancy and/or heart structure in aged mice arguing against a causative role of diminished I-1 expression for heart failure progression (Carr et al., 2002; El-Armouche et al., 2008; Heijman et al., 2013). Further studies are needed to better understand the functional implication of I-1 deletion during experimental models of heart failure and to elucidate if pharmacological inhibition of I-1 might be beneficial or detrimental during initiation and progression of heart failure. In contrast extreme overexpression of full-length I-1 (200-fold) led to spontaneous cardiac hypertrophy and cardiac dysfunction accompanied by compensatory PP1 expression already at young age of 3 months (El-Armouche et al., 2008). Instead conditional cardiomyocyte-specific and moderate overexpression of a constitutively active I-1 (I-1c) show a hypercontractile response comparable to PLB knock out mice but exaggerated contractile dysfunction upon catecholamine application in young mice and spontaneous development of dilated cardiomyopathy in adult mice (Wittkopper et al., 2010b, 2011). A comparative PP1 upregulation could however not be detected in this mouse model. Another study did not show any overt cardiac phenotypes in young mice after moderate I-1 overexpression and therefore postulated moderate I-1 overactivation/overexpression as a potential pharmacological approach (Pathak et al., 2005). Indeed subsequent studies using models of pressure overload and chronic isoprenaline infusion-induced heart failure, suggested that I-1 overexpression is associated with a preserved cardiac function, an attenuated development of cardiac hypertrophy and a lower degree of fibrosis and apoptosis (Pathak et al., 2005; Chen et al., 2010; Ishikawa et al., 2014).

A second example of I-1 controlled PP1 activity in a pathological condition has been described for the occurrence and persistence of atrial fibrillation (El-Armouche et al., 2006b; Chiang et al., 2015). Similar to the situation in failing myocardium some proteins which are important for $\mathrm{Ca}^{2+}$ handling, such as the L-type $\mathrm{Ca}^{2+}$ channel or cMyBP showed increased dephosphorylation hinting at hyperactive PPs (El-Armouche et al., 2006b; Dobrev and Nattel, 2008; Nattel et al., 2008). Nevertheless some other $\mathrm{Ca}^{2+}$-handling proteins like the RyR2 (at Ser2814) or PLB (at Thr17) were in turn hyper-phosphorylated arguing for rather subcellular than general upregulation of PP activity (Neef et al., 2010). The exact mechanism for this observation is however still unknown and deserves further investigation. Another contrast to the situation in failing myocardium were the level of I-1 as well as S67-phospho I1 , which were unchanged between $\mathrm{AF}$ and non-AF patients (Bhasin et al., 2007). Even more surprisingly, PKA-dependent phosphorylation of I- 1 at Thr35 was roughly 10 -fold higher in cAF patients, which is thought to be completely suppressive for SRbound PP1 activity, thus leading to increased phosphorylation of PLB (Ser16) and RyR2 (Ser2814; El-Armouche et al., 2006b; Chelu et al., 2009; Greiser et al., 2009). Another contributor toward RyR2 phosphorylation in cAF patients may be overactivated CaMKII which overcomes the globally enhanced PP1 activity causing greater steady-state RyR2 phosphorylation (Chelu et al., 2009).

As a final example for I-1 controlled PP activity during CVDs we have picked ventricular arrhythmias, which may be responsible for almost half of death cases in patients with heart failure (Packer, 1985; Roberts-Thomson et al., 2011). In general ventricular arrhythmias are initiated and maintained by either focal (ectopic) or re-entry mechanisms, which have been linked to increased diastolic SR $\mathrm{Ca}^{2+}$ leak from RyR2 and subsequent activation of the $\mathrm{Na}^{+} / \mathrm{Ca}^{2+}$-exchanger (NCX) at the cellular level (Weiss et al., 2000; Jalife et al., 2003; Prystowsky et al., 2012; Qu and Weiss, 2015). Increased and/or prolonged NCX activity may in turn lead to delayed after-depolarizations underlying arrhythmogenesis (Vermeulen et al., 1994; Schillinger et al., 2003; Sipido et al., 2007). Although still under debate if hyperactivated PKA or CaMKII play the major role for increased RyR2 activation and subsequent SR $\mathrm{Ca}^{2+}$ leak, it is common sense that $\beta$-adrenoceptor stimulation is the general trigger for $\mathrm{SR} \mathrm{Ca}^{2+}$ leak in both atrial and ventricular arrhythmias (Eisner et al., 2009; Eschenhagen, 2010; Dobrev et al., 2011). In contrast much less is known about the physiological and pathological role of RyR2 dephosphorylation by phosphatases. Different studies have shown that both, PP1 and PP2A are coupled to the RyR2 macromolecular complex (Marx et al., 2000). Consequently, the dual PP1/PP2A inhibitor okadaic acid increases the RyR2 open probability and phosphorylated RyR2 subunits have been shown to be dephosphorylated using recombinant PP1 (Sonnleitner et al., 1997).

Interestingly, I-1 deleted mice were partly protected from structural (hypertrophy, fibrosis, and dilatation) and functional effects (loss of inotropic response to dobutamine) of chronic $\beta$-adrenoceptor stimulation via isoprenaline infusions with minipumps (Wittkopper et al., 2011). In addition, injections of increasing doses of isoprenaline with continued ECG monitoring showed marked protection from fatal catecholamine induced arrhythmias in I-1 knock-out mice (El-Armouche et al., 2008). Notably, the protection from $\beta$-adrenergic-mediated cardiotoxicity in I-1 knock-out mice was not associated with changes in heart rate regulation. Further studies using, e.g., isoform-specific PP1 and/or PP2A overexpressing mice or cardiac myocytes may help to strengthen these preliminary results.

\section{Spinophilin}

Another fascinating example of phosphatase activity regulation with potential implication in CVD can be found within the interaction of spinophilin and PP1. First evidence that spinophilin can act as a regulatory PP1 subunits stems from in vitro co-immunoprecipitation studies using overexpressed GSTRyR2 fusion proteins (Marx et al., 2001). While in vitro coincubation of spinophilin and PP1 with the model substrate phosphorylase A led to decreased dephosphorylation activity, in 
vivo experiments showed that spinophilin acts as a scaffolding protein to target PP1 toward its endogenous substrates, thus rather facilitating dephosphorylation activity than decreasing it (Feng et al., 2000; Oliver et al., 2002). Elegant studies using different PP1/spinophilin or other PP1/PIP crystal complexes helped to understand the underlying mechanistic principles of these interactions (Ragusa et al., 2010, 2011).

It was shown that the C-terminal domain (aa 417-494) of spinophilin is necessary and sufficient for complete interaction with PP1 (Hsieh-Wilson et al., 1999). However, crystallization studies revealed that the PP1-binding domain of spinophilin is highly unstructured and has contact with multiple residues on PP1. In fact, the spinophilin binding domain entirely folds only upon binding to PP1 (Ragusa et al., 2010). Interestingly, spinophilin does not only bind via the well-recognized RVXF binding motif, but also by multiple interaction with the $\mathrm{C}$ terminal groove of PP1. Most importantly, despite all the above described PP1/spinophilin interaction sites, spinophilin does not affect the PP1 active site, nor two further putative substrate binding sites, enabling full PP1 activity when bound to spinophilin and leaving the chance for further PP1/PIP interactions. As a consequence really unique PP1 holoenzymes can exist, which may allow for very specific counteracting and fine-tuning of phosphorylation events conducted by the plethora of specific kinases within the cell. It would be of major interest to solve the structure of PP1/I-1 complexes as well, to better understand the nature of the so far mainly phenomenologically described interaction/inhibition.

Further reports showed that spinophilin is able to direct PP1 to the membrane of the SR in cardiac myocytes. Cardiomyocytes from spinophilin knock out mice revealed significantly reduced length, increased $\mathrm{Ca}^{2+}$ amplitude as well as maximal rate of $\mathrm{Ca}^{2+}$ rise during systole, decreased shortening amplitude and maximal rate of shortening, while $\beta$-adrenergic stimulation remained intact (Petzhold et al., 2011). Mechanistic studies suggested that spinophilin-mediated PP1 targeting to RyR2 and Phospholamban lead to site-specific enhanced dephosphorylation, thus evoking the phenotypic consequences described in the latter study. Very recently the group around Xander Wehrens transferred this knowledge into better understanding of disease mechanisms in atrial fibrillation putatively underlying deregulated PP1/spinophilin interactions and subsequent hyperactivation of RyR2 (Chiang et al., 2014). In detail they found that knockout of sphinophilin-1 resulted in strongly reduced interaction of PP1 and RyR2, while RyR2 phosphorylation was significantly increased at serine (Ser) 2814 but unchanged at Ser2808. As a result RyR2s from spinophilin-1 KO mice showed the expected increase in RyR2 open probability in lipid bilayer experiments, increased $\mathrm{Ca}^{2+}$ spark frequency in isolated atrial myocytes, which could be reverted by CaMKII inhibition, and most importantly increased atrial ectopy and susceptibility to pacing-induced atrial fibrillation in vivo, which could be reverted by crossing in phosphorylation-dead RyR2Ser2814A mice (Chiang et al., 2014). In summary this reports showed the first time that decreased local PP1 regulation of RyR2 contributes to RyR2 hyperactivity and promotion of atrial fibrillation susceptibility. This milestone study may set the basis for more exact examination of localized PP activity in CVDs, thus enabling novel drug targeting strategies in the future.

The last chapter of PP-dependent PK activity regulation will be opened in the upcoming section of this review. Hereby direct activity control of PKs via PP-mediated dephosphorylation will be discussed in light of a rapid molecular mechanism to achieve direct feedback control of PK activity.

\section{DIRECT CONTROL OF PROTEIN KINASE EXPRESSION AND ACTIVITY BY PROTEIN PHOSPHATASES}

It is a basic principle that PKs themselves are activated by (auto-)phosphorylation (Ubersax and Ferrell, 2007). In order to avoid excessive PK activation it is necessary that in most cases PK phosphorylation has to be reversible. Indeed several examples (see also Table 1) show direct PP-mediated dephosphorylation of PKs in cardiac cells. However, PP-mediated dephosphorylation of two of the most abundant and essential PKs in cardiac myocytes, namely PKA and CaMKII has only be studied in non-cardiac tissues until today (Blitzer et al., 1998; Bradshaw et al., 2003; Humphries et al., 2005; Otmakhov et al., 2015).

Dephosphorylation of PKA at position Thr-197 by PP2A was shown in vitro and in vivo. Interestingly, dephosphorylation activity strongly depends on oxidative state, which is mechanistically mediated via the neighboring cysteine 199 (Humphries et al., 2005). CaMKII is auto-activated at position Thr286 and can be dephosphorylated by PP1 and PP2B (Reese et al., 2011). In this case the dephosphorylation activity in dendritic spines is calcium dependent. It is tempting to speculate that PKA as well as CaMKII are also direct substrates of PPmediated dephosphorylation in cardiac physiology and especially in CVDs, thus predisposing further studies to clarify this issue.

In addition, there is yet another possibility of more or less direct control of PK activity by PP mediated initiation of alternative splicing in cardiac myocytes. The best studied example in this case is the CaMKII $\delta$-isoform, which plays an important role during evolvement of heart failure and cardiac arrhythmias (Gray and Heller Brown, 2014). Over- or deregulated expression of single splicing variants of CaMKII $\delta$ are sufficient to induce cardiac hypertrophy, dilated cardiomyopathy and subsequent heart failure in experimental animal models (Erickson, 2014). Two studies have shown that reversible phosphorylation of the splicing factor SF2/ASF by PKA and PP1 is able to change the splicing pattern of CaMKII $\delta$ and subsequently trigger functional consequences on typical CaMKII substrates such as PLB (Gu et al., 2011; Huang et al., 2014).

As described before Histones, Histone Deacetylases as well as transcription and translation factors have also been identified as PP substrates (Backs et al., 2006; Heijman et al., 2013; Kreusser and Backs, 2014). All these components are necessary prerequisites for (epi-)genetic control of PK activity. Finally, as CaMKII $\delta$ is by far not the only cardiac PK undergoing alternative splicing it will be worth to examine this novel way of PP-mediated PK regulation in more detail in the future. Regulation of alternative splicing in cardiac myocytes has emerged as a highly innovative 
and novel drug target in multiple studies and would be interesting to better understand the contribution of PPs in this regard. This conclusion closes the gap toward the final chapter of this review, which discusses the current state-of-the-art knowledge regarding pharmacological PP activity control that may serve as an additional or synergistic therapeutic approach toward pharmacological compounds targeting PKs.

\section{THERAPEUTIC PERSPECTIVE}

The widespread tasks of PP1, PP2A, and PP2B in healthy and diseased described in the chapter above, predispose the PPs as novel drug targets. In order to receive similar attention as kinase inhibitors, there are however still some challenges that have to be tackled.

The most straightforward approach to block the activity of an enzyme is the design of small molecules (SMOLs) which bind to the active site of the enzyme, thus blocking access for their endogenous substrates. Due to the very high structural conservation in PP1's catalytic site with that of PP2A, it has remained difficult to specifically target the active site of either phosphatase (Terrak et al., 2004; Cho and Xu, 2007). Nevertheless, some natural toxins such as calyculin, cantharidin, tautomycin and okadaic acid did reveal subtle selectivity between PP1 and PP2A in vitro and have thus been employed the last decades to study the role of PP1 and PP2A in cellular signaling processes (Hescheler et al., 1988; Aggen et al., 1999; Fagerholm et al., 2010). Even better selectivity is achieved by the endogenous inhibitors of PP1 and PP2A. As an example the heat stable endogenous protein inhibitors Inhibitor-1 as well as Inhibitor- 2 specifically inhibit PP1 at very low nanomolar concentrations without affecting the any other known serine/threonine phosphatase (Kwon et al., 1997). The usefulness of the latter inhibitors in functional assays or as drug leads is limited by the size, availability, stability as well as the cellular permeability of these proteins, but they could nevertheless be used as starting points for peptide-based drug design (Chatterjee and Kohn, 2013). Due to the multitude of phosphatase substrates direct and solely targeting of a single phosphatase catalytic subunit will putatively be insufficient or induce serious toxic side effects so further strategies rely on either disrupting the interaction between (a) the catalytic and

\section{REFERENCES}

Abiria, S. A., and Colbran, R. J. (2010). CaMKII associates with CaV1.2 L-type calcium channels via selected $\beta$ subunits to enhance regulatory phosphorylation. J. Neurochem. 112, 150-161. doi: 10.1111/j.1471-4159.2009.06436.x

Aggen, J. B., Humphrey, J. M., Gauss, C. M., Huang, H. B., Nairn, A. C., and Chamberlin, A. R. (1999). The design, synthesis, and biological evaluation of analogues of the serine-threonine protein phosphatase 1 and 2A selective inhibitor microcystin LA: rational modifications imparting PP1 selectivity. Bioorg. Med. Chem. 7, 543-564. doi: 10.1016/S0968-0896(98) 00254-5

Aitken, A., and Cohen, P. (1982). Isolation and characterisation of active fragments of protein phosphatase inhibitor-1 from rabbit skeletal muscle. FEBS Lett. 147, 54-58. doi: 10.1016/0014-5793(82)81010-7

Ai, X., Jiang, A., Ke, Y., Solaro, R. J., and Pogwizd, S. M. (2011). Enhanced activation of p21-activated kinase 1 in heart failure contributes to dephosphorylation of connexin 43. Cardiovasc. Res. 92, 106-114. doi: 10.1093/cvr/cvr163 respective regulatory subunit or (b) the regulatory subunit and the respective substrate. As a proof-of-concept specific modulators of PP1 (and PP2A) holoenzymes have been developed not only for the treatment of CVDs but also for the treatment of diabetes, Parkinson's disease and drug addiction (Uehata et al., 1997; Armstrong et al., 1998; McConnell and Wadzinski, 2009; Yger and Girault, 2011). Concrete examples are disruption of the PP1/GADD34 complex by salubrinal or guanabenz or I-1/I-2 overexpression in rodent/pig models of myocardial infarction (Boyce et al., 2005; Tsaytler et al., 2011; Liu et al., 2012; Neuber et al., 2014). Moreover synthetic peptides containing the PP1c-binding motif $(\mathrm{RVxF})$ have been successfully used to disrupt PP1 complexes in a neuronal and cardiac context, inducing beneficial effects on synaptic transmission and PLB phosphorylation (Reither et al., 2013; Sotoud et al., 2015). Thus, clinical targeting of PPs side-by-side with PK inhibition may represent a promising opportunity to treat CVDs in the near future.

Last but not least we propose two novel strategies to further enhance the feasibility of PP targeting drugs in CVDs: 1. Engaging subcellular and isotype-specific control of PPs: a recent review has highlighted the isotype-specific interaction of PP1 with different regulatory subunits and inhibitors. Combined with compartment-specific PP1 targeting this knowledge might lead to the development of really specific PP targeting drugs. 2. Combination of $\mathrm{PK}$ inhibitor and Phosphatase activating drugs and vice versa: in order to increase potency of currently used drugs, exact knowledge about the contribution of kinases and phosphatases during reversible protein phosphorylation of a specific substrate may help to develop novel and successful combination therapies-similar to the success story of LCZ696/Entresto (Gu et al., 2010; Solomon et al., 2012; Jessup et al., 2014; Desai et al., 2015).

\section{FUNDING}

The work in authors' laboratory is supported by the Deutsche Forschungsgemeinschaft (EL 270/5-1, SFB 1002; AE-A); Faculty of Medicine, TU Dresden (MeDDrive, SW); ESAC Deutschland e.V. (MW) and European Network for Translational Research in Atrial Fibrillation (EUTRAF, No. 261057, DD), DZHK (German Center for Cardiovascular Research, DD).

Ai, X., and Pogwizd, S. M. (2005). Connexin 43 downregulation and dephosphorylation in nonischemic heart failure is associated with enhanced colocalized protein phosphatase type 2A. Circ. Res. 96, 54-63. doi: 10.1161/01.RES.0000152325.07495.5a

Aleem, E. A., Flohr, T., Hunziker, A., Mayer, D., Bannasch, P., and Thielmann, H. W. (2001). Detection and quantification of protein phosphatase inhibitor-1 gene expression in total rat liver and isolated hepatocytes. Mol. Cell. Biochem. 217, 1-12. doi: 10.1023/A:1007141514750

Aoyama, H., Ikeda, Y., Miyazaki, Y., Yoshimura, K., Nishino, S., Yamamoto, T., et al. (2011). Isoform-specific roles of protein phosphatase 1 catalytic subunits in sarcoplasmic reticulum-mediated $\mathrm{Ca}^{2+}$ cycling. Cardiovasc. Res. 89, 79-88. doi: $10.1093 / \mathrm{cvr} / \mathrm{cvq} 252$

Armstrong, C. G., Doherty, M. J., and Cohen, P. T. (1998). Identification of the separate domains in the hepatic glycogen-targeting subunit of protein phosphatase 1 that interact with phosphorylase a, glycogen and protein phosphatase 1. Biochem. J. 336, 699-704. doi: 10.1042/bj3 360699 
Ashpole, N. M., Herren, A. W., Ginsburg, K. S., Brogan, J. D., Johnson, D. E., Cummins, T. R., et al. (2012). $\mathrm{Ca}^{2+} /$ calmodulin-dependent protein kinase II (CaMKII) regulates cardiac sodium channel NaV1.5 gating by multiple phosphorylation sites. J. Biol. Chem. 287, 19856-19869. doi: 10.1074/jbc.M111.322537

Auger-Messier, M., Accornero, F., Goonasekera, S. A., Bueno, O. F., Lorenz, J. N., Van Berlo, J. H., et al. (2013). Unrestrained p38 MAPK activation in Dusp1/4 double-null mice induces cardiomyopathy. Circ. Res. 112, 48-56. doi: 10.1161/CIRCRESAHA.112.272963

Awad, S., Kunhi, M., Little, G. H., Bai, Y., An, W., Bers, D., et al. (2013). Nuclear CaMKII enhances histone $\mathrm{H} 3$ phosphorylation and remodels chromatin during cardiac hypertrophy. Nucleic Acids Res. 41, 7656-7672. doi: 10.1093/nar/gkt500

Aye, T. T., Soni, S., Van Veen, T. A., Van Der Heyden, M. A., Cappadona, S., Varro, A., et al. (2012). Reorganized PKA-AKAP associations in the failing human heart. J. Mol. Cell Cardiol. 52, 511-518. doi: 10.1016/j.yjmcc.2011.06.003

Baba, S., Dun, W., and Boyden, P. A. (2004). Can PKA activators rescue $\mathrm{Na}^{+}$ channel function in epicardial border zone cells that survive in the infarcted canine heart? Cardiovasc. Res. 64, 260-267. doi: 10.1016/j.cardiores.2004.06.021

Backs, J., Song, K., Bezprozvannaya, S., Chang, S., and Olson, E. N. (2006). CaM kinase II selectively signals to histone deacetylase 4 during cardiomyocyte hypertrophy. J. Clin. Invest. 116, 1853-1864. doi: 10.1172/JCI27438

Barefield, D., and Sadayappan, S. (2010). Phosphorylation and function of cardiac myosin binding protein-C in health and disease. J. Mol. Cell Cardiol. 48, 866-875. doi: 10.1016/j.yjmcc.2009.11.014

Beals, C. R., Sheridan, C. M., Turck, C. W., Gardner, P., and Crabtree, G. R. (1997). Nuclear export of NF-ATc enhanced by glycogen synthase kinase-3. Science 275, 1930-1934. doi: 10.1126/science.275.5308.1930

Belevych, A. E., Sansom, S. E., Terentyeva, R., Ho, H. T., Nishijima, Y., Martin, M. M., et al. (2011). MicroRNA-1 and -133 increase arrhythmogenesis in heart failure by dissociating phosphatase activity from RyR2 complex. PLoS ONE 6:e28324. doi: 10.1371/journal.pone.0028324

Belmonte, S. L., and Blaxall, B. C. (2011). G protein coupled receptor kinases as therapeutic targets in cardiovascular disease. Circ. Res. 109, 309-319. doi: 10.1161/CIRCRESAHA.110.231233

Berrebi-Bertrand, I., Souchet, M., Camelin, J. C., Laville, M. P., Calmels, T., and Bril, A. (1998). Biophysical interaction between phospholamban and protein phosphatase 1 regulatory subunit GM. FEBS Lett. 439, 224-230. doi: 10.1016/S0014-5793(98)01364-7

Bers, D. M., and Herren, A. W. (2012). $\mathrm{Na}^{+}$channel I-II loop mediates parallel genetic and phosphorylation-dependent gating changes. Circulation 126, 2042-2046. doi: 10.1161/CIRCULATIONAHA.112.140384

Bettoun, D. J., Buck, D. W. II, Lu, J., Khalifa, B., Chin, W. W., and Nagpal, S. (2002). A vitamin D receptor-Ser/Thr phosphatase-p70 S6 kinase complex and modulation of its enzymatic activities by the ligand. J. Biol. Chem. 277, 24847-24850. doi: 10.1074/jbc.C200187200

Bhasin, N., Cunha, S. R., Mudannayake, M., Gigena, M. S., Rogers, T. B., and Mohler, P. J. (2007). Molecular basis for PP2A regulatory subunit B56 $\alpha$ targeting in cardiomyocytes. Am. J. Physiol. Heart Circ. Physiol. 293, H109-H119. doi: 10.1152/ajpheart.00059.2007

Blaich, A., Welling, A., Fischer, S., Wegener, J. W., Kostner, K., Hofmann, F., et al. (2010). Facilitation of murine cardiac L-type $\mathrm{Ca}(\mathrm{v}) 1.2$ channel is modulated by calmodulin kinase II-dependent phosphorylation of S1512 and S1570. Proc. Natl. Acad. Sci. U.S.A. 107, 10285-10289. doi: 10.1073/pnas.0914287107

Blitzer, R. D., Connor, J. H., Brown, G. P., Wong, T., Shenolikar, S., Iyengar, R., et al. (1998). Gating of CaMKII by cAMP-regulated protein phosphatase activity during LTP. Science 280, 1940-1942. doi: 10.1126/science.280.53 71.1940

Bollen, M., and Beullens, M. (2002). Signaling by protein phosphatases in the nucleus. Trends Cell Biol. 12, 138-145. doi: 10.1016/S0962-8924(01)02247-4

Boon, R. A., Iekushi, K., Lechner, S., Seeger, T., Fischer, A., Heydt, S., et al. (2013). MicroRNA-34a regulates cardiac ageing and function. Nature 495, 107-110. doi: 10.1038/nature11919

Bourajjaj, M., Armand, A. S., Da Costa Martins, P. A., Weijts, B., Van Der Nagel, R., Heeneman, S., et al. (2008). NFATc2 is a necessary mediator of calcineurin-dependent cardiac hypertrophy and heart failure. J. Biol. Chem. 283, 22295-22303. doi: 10.1074/jbc.M801296200

Boyce, M., Bryant, K. F., Jousse, C., Long, K., Harding, H. P., Scheuner, D., et al. (2005). A selective inhibitor of eIF2 dephosphorylation protects cells from ER stress. Science 307, 935-939. doi: 10.1126/science.1101902
Bradshaw, J. M., Kubota, Y., Meyer, T., and Schulman, H. (2003). An ultrasensitive $\mathrm{Ca}^{2+} /$ calmodulin-dependent protein kinase II-protein phosphatase 1 switch facilitates specificity in postsynaptic calcium signaling. Proc. Natl. Acad. Sci. U.S.A. 100, 10512-10517. doi: 10.1073/pnas. 1932759100

Brandl, C. J., Green, N. M., Korczak, B., and Maclennan, D. H. (1986). Two Ca ${ }^{2+}$ ATPase genes: homologies and mechanistic implications of deduced amino acid sequences. Cell 44, 597-607. doi: 10.1016/0092-8674(86)90269-2

Brandmayr, J., Poomvanicha, M., Domes, K., Ding, J., Blaich, A., Wegener, J. W., et al. (2012). Deletion of the C-terminal phosphorylation sites in the cardiac $\beta$-subunit does not affect the basic $\beta$-adrenergic response of the heart and the Ca(v)1.2 channel. J. Biol. Chem. 287, 22584-22592. doi: 10.1074/jbc.M112.366484

Braz, J. C., Gregory, K., Pathak, A., Zhao, W., Sahin, B., Klevitsky, R., et al. (2004). PKC- regulates cardiac contractility and propensity toward heart failure. Nat. Med. 10, 248-254. doi: 10.1038/nm1000

Brinkworth, R. I., Breinl, R. A., and Kobe, B. (2003). Structural basis and prediction of substrate specificity in protein serine/threonine kinases. Proc. Natl. Acad. Sci. U.S.A. 100, 74-79. doi: 10.1073/pnas. 0134224100

Carlisle Michel, J. J., Dodge, K. L., Wong, W., Mayer, N. C., Langeberg, L. K., and Scott, J. D. (2004). PKA-phosphorylation of PDE4D3 facilitates recruitment of the mAKAP signalling complex. Biochem. J. 381, 587-592. doi: $10.1042 / B J 20040846$

Carr, A. N., Schmidt, A. G., Suzuki, Y., Del Monte, F., Sato, Y., Lanner, C., et al. (2002). Type 1 phosphatase, a negative regulator of cardiac function. Mol. Cell. Biol. 22, 4124-4135. doi: 10.1128/MCB.22.12.4124-4135.2002

Ceulemans, H., and Bollen, M. (2004). Functional diversity of protein phosphatase1, a cellular economizer and reset button. Physiol. Rev. 84, 1-39. doi: 10.1152/physrev.00013.2003

Chatterjee, J., and Kohn, M. (2013). Targeting the untargetable: recent advances in the selective chemical modulation of protein phosphatase-1 activity. Curr. Opin. Chem. Biol. 17, 361-368. doi: 10.1016/j.cbpa.2013.04.008

Chelu, M. G., Sarma, S., Sood, S., Wang, S., Van Oort, R. J., Skapura, D. G., et al. (2009). Calmodulin kinase II-mediated sarcoplasmic reticulum $\mathrm{Ca}^{2+}$ leak promotes atrial fibrillation in mice. J. Clin. Invest. 119, 1940-1951. doi: $10.1172 /$ jci37059

Chemin, J., Mezghrani, A., Bidaud, I., Dupasquier, S., Marger, F., Barrere, C., et al. (2007). Temperature-dependent modulation of CaV3 T-type calcium channels by protein kinases $\mathrm{C}$ and A in mammalian cells. J. Biol. Chem. 282, 32710-32718. doi: 10.1074/jbc.M702746200

Chen, E. S., Zhang, K., Nicolas, E., Cam, H. P., Zofall, M., and Grewal, S. I. (2008). Cell cycle control of centromeric repeat transcription and heterochromatin assembly. Nature 451, 734-737. doi: 10.1038/nature06561

Chen, G., Zhou, X., Florea, S., Qian, J., Cai, W., Zhang, Z., et al. (2010). Expression of active protein phosphatase 1 inhibitor- 1 attenuates chronic $\beta$-agonist-induced cardiac apoptosis. Basic Res. Cardiol. 105, 573-581. doi: 10.1007/s00395-0100106-3

Chen, X., Piacentino, V., III, Furukawa, S., Goldman, B., Margulies, K. B., and Houser, S. R. (2002). L-type $\mathrm{Ca}^{2+}$ channel density and regulation are altered in failing human ventricular myocytes and recover after support with mechanical assist devices. Circ. Res. 91, 517-524. doi: 10.1161/01.RES.0000033988.13062.7C

Cheung, J. Y., Zhang, X. Q., Song, J., Gao, E., Rabinowitz, J. E., Chan, T. O., et al. (2010). Phospholemman: a novel cardiac stress protein. Clin. Transl. Sci. 3, 189-196. doi: 10.1111/j.1752-8062.2010.00213.x

Chiang, D. Y., Lebesgue, N., Beavers, D. L., Alsina, K. M., Damen, J. M., Voigt, N., et al. (2015). Alterations in the interactome of serine/threonine protein phosphatase type-1 in atrial fibrillation patients. J. Am. Coll. Cardiol. 65, 163-173. doi: 10.1016/j.jacc.2014.10.042

Chiang, D. Y., Li, N., Wang, Q., Alsina, K. M., Quick, A. P., Reynolds, J. O., et al. (2014). Impaired local regulation of ryanodine receptor type 2 by protein phosphatase 1 promotes atrial fibrillation. Cardiovasc. Res. 103, 178-187. doi: $10.1093 / \mathrm{cvr} / \mathrm{cvu} 123$

Cho, U. S., and $\mathrm{Xu}, \mathrm{W}$. (2007). Crystal structure of a protein phosphatase 2A heterotrimeric holoenzyme. Nature 445, 53-57. doi: 10.1038/nature05351

Chouchani, E. T., Pell, V. R., Gaude, E., Aksentijevic, D., Sundier, S. Y., Robb, E. L., et al. (2014). Ischaemic accumulation of succinate controls reperfusion injury through mitochondrial ROS. Nature 515, 431-435. doi: 10.1038/nature13909

Chow, C. W., and Davis, R. J. (2000). Integration of calcium and cyclic AMP signaling pathways by 14-3-3. Mol. Cell. Biol. 20, 702-712. doi: 10.1128/MCB.20.2.702-712.2000 
Chow, C. W., Dong, C., Flavell, R. A., and Davis, R. J. (2000). c-Jun $\mathrm{NH}_{2}$-terminal kinase inhibits targeting of the protein phosphatase calcineurin to NFATc1. Mol. Cell. Biol. 20, 5227-5234. doi: 10.1128/MCB.20.14.5227-5234.2000

Chow, C. W., Rincon, M., Cavanagh, J., Dickens, M., and Davis, R. J. (1997). Nuclear accumulation of NFAT4 opposed by the JNK signal transduction pathway. Science 278, 1638-1641. doi: 10.1126/science.278.5343.1638

Chu, G., and Kranias, E. G. (2002). Functional interplay between dual site phospholamban phosphorylation: insights from genetically altered mouse models. Basic Res. Cardiol. 97(Suppl. 1), I43-48. doi: 10.1007/s003950200028

Cohen, P. (1989). The structure and regulation of protein phosphatases. Annu. Rev. Biochem. 58, 453-508. doi: 10.1146/annurev.bi.58.070189.002321

Cohen, P. (2002a). The origins of protein phosphorylation. Nat. Cell Biol. 4, E127-E130. doi: 10.1038/ncb0502-e127

Cohen, P. (2002b). Protein kinases-the major drug targets of the twenty-first century? Nat. Rev. Drug. Discov. 1, 309-315. doi: 10.1038/nrd773

Cohen, P. T. (2002c). Protein phosphatase 1-targeted in many directions. J. Cell Sci. $115,241-256$.

Cole, H. A., and Perry, S. V. (1975). The phosphorylation of troponin I from cardiac muscle. Biochem. J. 149, 525-533. doi: 10.1042/bj1490525

Comerford, K. M., Leonard, M. O., Cummins, E. P., Fitzgerald, K. T., Beullens, M., Bollen, M., et al. (2006). Regulation of protein phosphatase $1 \gamma$ activity in hypoxia through increased interaction with NIPP1: implications for cellular metabolism. J. Cell. Physiol. 209, 211-218. doi: 10.1002/jcp.20726

Cori, C. F., Schmidt, G., and Cori, G. T. (1939). The synthesis of a polysaccharide from glucose-1-phosphate in muscle extract. Science 89, 464-465. doi: 10.1126/science.89.2316.464

Davare, M. A., Horne, M. C., and Hell, J. W. (2000). Protein phosphatase 2A is associated with class C L-type calcium channels (Cav1.2) and antagonizes channel phosphorylation by cAMP-dependent protein kinase. J. Biol. Chem. 275, 39710-39717. doi: 10.1074/jbc.M005462200

De Arcangelis, V., Soto, D., and Xiang, Y. (2008). Phosphodiesterase 4 and phosphatase $2 \mathrm{~A}$ differentially regulate $\mathrm{cAMP} /$ protein kinase a signaling for cardiac myocyte contraction under stimulation of $\beta 1$ adrenergic receptor. Mol. Pharmacol. 74, 1453-1462. doi: 10.1124/mol.108.049718

DeGrande, S. T., Little, S. C., Nixon, D. J., Wright, P., Snyder, J., Dun, W., et al. (2013). Molecular mechanisms underlying cardiac protein phosphatase 2A regulation in heart. J. Biol. Chem. 288, 1032-1046. doi: 10.1074/jbc.M112.426957

Delmar, M., and Makita, N. (2012). Cardiac connexins, mutations and arrhythmias. Curr. Opin. Cardiol. 27, 236-241. doi: 10.1097/HCO.0b013e328352220e

De Munter, S., Kohn, M., and Bollen, M. (2013). Challenges and opportunities in the development of protein phosphatase-directed therapeutics. ACS Chem. Biol. 8, 36-45. doi: 10.1021/cb300597g

Desai, A. S., Mcmurray, J. J., Packer, M., Swedberg, K., Rouleau, J. L., Chen, F., et al. (2015). Effect of the angiotensin-receptor-neprilysin inhibitor LCZ696 compared with enalapril on mode of death in heart failure patients. Eur. Heart J. 36, 1990-1997. doi: 10.1093/eurheartj/ehv186

Djouder, N., Metzler, S. C., Schmidt, A., Wirbelauer, C., Gstaiger, M., Aebersold, R., et al. (2007). S6K1-mediated disassembly of mitochondrial URI/PP1 $\gamma$ complexes activates a negative feedback program that counters S6K1 survival signaling. Mol. Cell. 28, 28-40. doi: 10.1016/j.molcel.2007.08.010

Dobrev, D., and Nattel, S. (2008). Calcium handling abnormalities in atrial fibrillation as a target for innovative therapeutics. J. Cardiovasc. Pharmacol. 52, 293-299. doi: 10.1097/FJC.0b013e318171924d

Dobrev, D., Voigt, N., and Wehrens, X. H. (2011). The ryanodine receptor channel as a molecular motif in atrial fibrillation: pathophysiological and therapeutic implications. Cardiovasc. Res. 89, 734-743. doi: 10.1093/cvr/ cvq324

Dodge-Kafka, K. L., Bauman, A., Mayer, N., Henson, E., Heredia, L., Ahn, J., et al. (2010). cAMP-stimulated protein phosphatase 2A activity associated with muscle A kinase-anchoring protein (mAKAP) signaling complexes inhibits the phosphorylation and activity of the cAMP-specific phosphodiesterase PDE4D3. J. Biol. Chem. 285, 11078-11086. doi: 10.1074/jbc.M109.034868

Dodge-Kafka, K. L., Langeberg, L., and Scott, J. D. (2006). Compartmentation of cyclic nucleotide signaling in the heart: the role of A-kinase anchoring proteins. Circ. Res. 98, 993-1001. doi: 10.1161/01.RES.0000218273.91741.30

Domes, K., Ding, J., Lemke, T., Blaich, A., Wegener, J. W., Brandmayr, J., et al. (2011). Truncation of murine CaV1.2 at Asp-1904 results in heart failure after birth. J. Biol. Chem. 286, 33863-33871. doi: 10.1074/jbc.M111.252312
Egloff, M. P., Johnson, D. F., Moorhead, G., Cohen, P. T., Cohen, P., and Barford, D. (1997). Structural basis for the recognition of regulatory subunits by the catalytic subunit of protein phosphatase 1 . EMBO J. 16, 1876-1887. doi: 10.1093/emboj/16.8.1876

Eisner, D. A., Kashimura, T., O'neill, S. C., Venetucci, L. A., and Trafford, A. W. (2009). What role does modulation of the ryanodine receptor play in cardiac inotropy and arrhythmogenesis? J. Mol. Cell. Cardiol. 46, 474-481. doi: 10.1016/j.yjmcc.2008.12.005

El-Armouche, A., Bednorz, A., Pamminger, T., Ditz, D., Didie, M., Dobrev, D., et al. (2006a). Role of calcineurin and protein phosphatase-2A in the regulation of phosphatase inhibitor-1 in cardiac myocytes. Biochem. Biophys. Res. Commun. 346, 700-706. doi: 10.1016/j.bbrc.2006.05.182

El-Armouche, A., Boknik, P., Eschenhagen, T., Carrier, L., Knaut, M., Ravens, U., et al. (2006b). Molecular determinants of altered $\mathrm{Ca}^{2+}$ handling in human chronic atrial fibrillation. Circulation 114, 670-680. doi: 10.1161/CIRCULATIONAHA.106.636845

El-Armouche, A., and Eschenhagen, T. (2009). $\beta$-adrenergic stimulation and myocardial function in the failing heart. Heart Fail. Rev. 14, 225-241. doi: 10.1007/s10741-008-9132-8

El-Armouche, A., Gocht, F., Jaeckel, E., Wittkopper, K., Peeck, M., and Eschenhagen, T. (2007a). Long-term $\beta$-adrenergic stimulation leads to downregulation of protein phosphatase inhibitor-1 in the heart. Eur. J. Heart Fail. 9, 1077-1080. doi: 10.1016/j.ejheart.2007.09.006

El-Armouche, A., Pohlmann, L., Schlossarek, S., Starbatty, J., Yeh, Y. H., Nattel, S., et al. (2007b). Decreased phosphorylation levels of cardiac myosin-binding protein-C in human and experimental heart failure. J. Mol. Cell Cardiol. 43, 223-229. doi: 10.1016/j.yjmcc.2007.05.003

El-Armouche, A., Pamminger, T., Ditz, D., Zolk, O., and Eschenhagen, T. (2004). Decreased protein and phosphorylation level of the protein phosphatase inhibitor-1 in failing human hearts. Cardiovasc. Res. 61, 87-93. doi: 10.1016/j.cardiores.2003.11.005

El-Armouche, A., Rau, T., Zolk, O., Ditz, D., Pamminger, T., Zimmermann, W. H., et al. (2003). Evidence for protein phosphatase inhibitor-1 playing an amplifier role in $\beta$-adrenergic signaling in cardiac myocytes. FASEB J. 17, 437-439. doi: 10.1096/fj.02-0057fje

El-Armouche, A., Wittkopper, K., Degenhardt, F., Weinberger, F., Didie, M., Melnychenko, I., et al. (2008). Phosphatase inhibitor-1-deficient mice are protected from catecholamine-induced arrhythmias and myocardial hypertrophy. Cardiovasc. Res. 80, 396-406. doi: 10.1093/cvr/cvn208

El-Armouche, A., Wittkopper, K., Fuller, W., Howie, J., Shattock, M. J., and Pavlovic, D. (2011). Phospholemman-dependent regulation of the cardiac Na/K-ATPase activity is modulated by inhibitor-1 sensitive type-1 phosphatase. FASEB J. 25, 4467-4475. doi: 10.1096/fj.11-184903

Endo, S., Zhou, X., Connor, J., Wang, B., and Shenolikar, S. (1996). Multiple structural elements define the specificity of recombinant human inhibitor1 as a protein phosphatase-1 inhibitor. Biochemistry 35, 5220-5228. doi: 10.1021/bi952940f

Erickson, J. R. (2014). Mechanisms of CaMKII Activation in the Heart. Front. Pharmacol. 5:59. doi: 10.3389/fphar.2014.00059

Eschenhagen, T. (2010). Is ryanodine receptor phosphorylation key to the fight or flight response and heart failure? J. Clin. Invest. 120, 4197-4203. doi: $10.1172 /$ JCI45251

Fagerholm, A. E., Habrant, D., and Koskinen, A. M. (2010). Calyculins and related marine natural products as serine-threonine protein phosphatase PP1 and PP2A inhibitors and total syntheses of calyculin A, B, and C. Mar. Drugs 8, 122-172. doi: $10.3390 / \mathrm{md} 80100122$

Felkin, L. E., Narita, T., Germack, R., Shintani, Y., Takahashi, K., Sarathchandra, P., et al. (2011). Calcineurin splicing variant calcineurin $A \beta 1$ improves cardiac function after myocardial infarction without inducing hypertrophy. Circulation 123, 2838-2847. doi: 10.1161/CIRCULATIONAHA.110.012211

Feng, J., Yan, Z., Ferreira, A., Tomizawa, K., Liauw, J. A., Zhuo, M., et al. (2000). Spinophilin regulates the formation and function of dendritic spines. Proc. Natl. Acad. Sci. U.S.A. 97, 9287-9292. doi: 10.1073/pnas.97.16.9287

Feschenko, M. S., and Sweadner, K. J. (1997). Phosphorylation of Na,K-ATPase by protein kinase $\mathrm{C}$ at Ser18 occurs in intact cells but does not result in direct inhibition of ATP hydrolysis. J. Biol. Chem. 272, 17726-17733. doi: 10.1074/jbc.272.28.17726

Florea, S., Anjak, A., Cai, W. F., Qian, J., Vafiadaki, E., Figueria, S., et al. (2012). Constitutive phosphorylation of inhibitor-1 at Ser67 and Thr75 depresses 
calcium cycling in cardiomyocytes and leads to remodeling upon aging. Basic Res. Cardiol. 107, 279. doi: 10.1007/s00395-012-0279-z

Force, T., Kuida, K., Namchuk, M., Parang, K., and Kyriakis, J. M. (2004). Inhibitors of protein kinase signaling pathways: emerging therapies for cardiovascular disease. Circulation 109, 1196-1205. doi: 10.1161/01.CIR.0000118538.21306.A9

Gerhardstein, B. L., Puri, T. S., Chien, A. J., and Hosey, M. M. (1999). Identification of the sites phosphorylated by cyclic AMP-dependent protein kinase on the $\beta 2$ subunit of L-type voltage-dependent calcium channels. Biochemistry 38, 10361-10370. doi: 10.1021/bi990896o

Gomez del Arco, P., Martinez-Martinez, S., Maldonado, J. L., Ortega-Perez, I., and Redondo, J. M. (2000). A role for the p38 MAP kinase pathway in the nuclear shuttling of NFATp. J. Biol. Chem. 275, 13872-13878. doi: $10.1074 / j b c .275 .18 .13872$

Gray, C. B., and Heller Brown, J. (2014). CaMKIIdelta subtypes: localization and function. Front. Pharmacol. 5:15. doi: 10.3389/fphar.2014.00015

Greiser, M., Neuberger, H. R., Harks, E., El-Armouche, A., Boknik, P., De Haan, S., et al. (2009). Distinct contractile and molecular differences between two goat models of atrial dysfunction: AV block-induced atrial dilatation and atrial fibrillation. J. Mol. Cell Cardiol. 46, 385-394. doi: 10.1016/j.yjmcc.2008.11.012

Grueter, C. E., Abiria, S. A., Dzhura, I., Wu, Y., Ham, A. J., Mohler, P. J., et al. (2006). L-type $\mathrm{Ca}^{2+}$ channel facilitation mediated by phosphorylation of the $\beta$ subunit by CaMKII. Mol. Cell. 23, 641-650. doi: 10.1016/j.molcel.2006.07.006

Gu, J., Noe, A., Chandra, P., Al-Fayoumi, S., Ligueros-Saylan, M., Sarangapani, R., et al. (2010). Pharmacokinetics and pharmacodynamics of LCZ696, a novel dualacting angiotensin receptor-neprilysin inhibitor (ARNi). J. Clin. Pharmacol. 50, 401-414. doi: 10.1177/0091270009343932

Gu, Q., Jin, N., Sheng, H., Yin, X., and Zhu, J. (2011). Cyclic AMP-dependent protein kinase A regulates the alternative splicing of CaMKIIdelta. PLoS ONE 6:e25745. doi: 10.1371/journal.pone.0025745

Gupta, R. C., Mishra, S., Rastogi, S., Imai, M., Habib, O., and Sabbah, H. N. (2003). Cardiac SR-coupled PP1 activity and expression are increased and inhibitor 1 protein expression is decreased in failing hearts. Am. J. Physiol. Heart Circ. Physiol. 285, H2373-H2381. doi: 10.1152/ajpheart.00442.2003

Gwack, Y., Sharma, S., Nardone, J., Tanasa, B., Iuga, A., Srikanth, S., et al. (2006). A genome-wide Drosophila RNAi screen identifies DYRK-family kinases as regulators of NFAT. Nature 441, 646-650. doi: 10.1038/nature04631

Hall, D. D., Feekes, J. A., Arachchige Don, A. S., Shi, M., Hamid, J., Chen, L., et al. (2006). Binding of protein phosphatase $2 \mathrm{~A}$ to the L-type calcium channel Cav1.2 next to Ser1928, its main PKA site, is critical for Ser1928 dephosphorylation. Biochemistry 45, 3448-3459. doi: 10.1021/bi051593z

Harvey, R. D. (2004). Regulation of cardiac Na-Ca exchange activity by selective tyrosine kinase inhibition. Br. J. Pharmacol. 143, 929-930. doi: 10.1038/sj.bjp.0706009

Heijman, J., Dewenter, M., El-Armouche, A., and Dobrev, D. (2013). Function and regulation of serine/threonine phosphatases in the healthy and diseased heart. J. Mol. Cell Cardiol. 64, 90-98. doi: 10.1016/j.yjmcc.2013.09.006

Heineke, J., and Molkentin, J. D. (2006). Regulation of cardiac hypertrophy by intracellular signalling pathways. Nat. Rev. Mol. Cell Biol. 7, 589-600. doi: $10.1038 / \mathrm{nrm} 1983$

Heineke, J., and Ritter, O. (2012). Cardiomyocyte calcineurin signaling in subcellular domains: from the sarcolemma to the nucleus and beyond. J. Mol. Cell Cardiol. 52, 62-73. doi: 10.1016/j.yjmcc.2011.10.018

Hemmings, H. C. Jr., Girault, J. A., Nairn, A. C., Bertuzzi, G., and Greengard, P. (1992). Distribution of protein phosphatase inhibitor-1 in brain and peripheral tissues of various species: comparison with DARPP-32. J. Neurochem. 59, 1053-1061. doi: 10.1111/j.1471-4159.1992.tb08347.x

Herzig, S., and Neumann, J. (2000). Effects of serine/threonine protein phosphatases on ion channels in excitable membranes. Physiol. Rev. 80, 173-210.

Hescheler, J., Mieskes, G., Ruegg, J. C., Takai, A., and Trautwein, W. (1988). Effects of a protein phosphatase inhibitor, okadaic acid, on membrane currents of isolated guinea-pig cardiac myocytes. Pflugers. Arch. 412, 248-252. doi: 10.1007/BF00582504

Hong, T. T., Smyth, J. W., Chu, K. Y., Vogan, J. M., Fong, T. S., Jensen, B. C., et al. (2012). BIN1 is reduced and Cav1.2 trafficking is impaired in human failing cardiomyocytes. Heart Rhythm 9, 812-820. doi: 10.1016/j.hrthm.2011.11.055

Hsieh-Wilson, L. C., Allen, P. B., Watanabe, T., Nairn, A. C., and Greengard, P. (1999). Characterization of the neuronal targeting protein spinophilin and its interactions with protein phosphatase-1. Biochemistry 38, 4365-4373. doi: $10.1021 / \mathrm{bi} 982900 \mathrm{~m}$
Huang, B., Wang, S., Qin, D., Boutjdir, M., and El-Sherif, N. (1999). Diminished basal phosphorylation level of phospholamban in the postinfarction remodeled rat ventricle: role of $\beta$-adrenergic pathway, $G(i)$ protein, phosphodiesterase, and phosphatases. Circ. Res. 85, 848-855. doi: 10.1161/01.RES.85.9.848

Huang, C., Cao, W., Liao, R., Wang, J., Wang, Y., Tong, L., et al. (2014). PP1 $\gamma$ functionally augments the alternative splicing of CaMKIIdelta through interaction with ASF. Am. J. Physiol. Cell Physiol. 306, C167-C177. doi: 10.1152/ajpcell.00145.2013

Huang, F. L., and Glinsmann, W. H. (1976). Separation and characterization of two phosphorylase phosphatase inhibitors from rabbit skeletal muscle. Eur. J. Biochem. 70, 419-426. doi: 10.1111/j.1432-1033.1976.tb11032.x

Huang, K. X., and Paudel, H. K. (2000). Ser67-phosphorylated inhibitor 1 is a potent protein phosphatase 1 inhibitor. Proc. Natl. Acad. Sci. U.S.A. 97, 5824-5829. doi: 10.1073/pnas. 100460897

Huang, Y. C., Chen, Y. C., Tsay, H. J., Chyan, C. L., Chen, C. Y., Huang, H. B., et al. (2010). The effect of PKA-phosphorylation on the structure of inhibitor-1 studied by NMR spectroscopy. J. Biochem. 147, 273-278. doi: $10.1093 / \mathrm{jb} / \mathrm{mvp} 178$

Hu, C., Depuy, S. D., Yao, J., Mcintire, W. E., and Barrett, P. Q. (2009). Protein kinase A activity controls the regulation of T-type CaV3.2 channels by G $\beta \gamma$ dimers. J. Biol. Chem. 284, 7465-7473. doi: 10.1074/jbc.M808049200

Hulme, J. T., Westenbroek, R. E., Scheuer, T., and Catterall, W. A. (2006). Phosphorylation of serine 1928 in the distal C-terminal domain of cardiac CaV1.2 channels during $\beta 1$-adrenergic regulation. Proc. Natl. Acad. Sci. U.S.A. 103, 16574-16579. doi: 10.1073/pnas.0607294103

Humphries, K. M., Deal, M. S., and Taylor, S. S. (2005). Enhanced dephosphorylation of cAMP-dependent protein kinase by oxidation and thiol modification. J. Biol. Chem. 280, 2750-2758. doi: 10.1074/jbc.M4102 42200

Hund, T. J., Koval, O. M., Li, J., Wright, P. J., Qian, L., Snyder, J. S., et al. (2010). A $\beta(I V)$-spectrin/CaMKII signaling complex is essential for membrane excitability in mice. J. Clin. Invest. 120, 3508-3519. doi: 10.1172/JCI43621

Iacobazzi, D., Garaeva, I., Albertario, A., Cherif, M., Angelini, G. D., Caputo, M., et al. (2015). Protein phosphatase $1 \beta$ is modulated by chronic hypoxia and involved in the angiogenic endothelial cell migration. Cell Physiol. Biochem 36, 384-394. doi: $10.1159 / 000430257$

Ishikawa, K., Fish, K. M., Tilemann, L., Rapti, K., Aguero, J., Santos-Gallego, C. G., et al. (2014). Cardiac I-1c overexpression with reengineered AAV improves cardiac function in swine ischemic heart failure. Mol. Ther. 22, 2038-2045. doi: $10.1038 / \mathrm{mt} .2014 .127$

Jackson, W. A., and Colyer, J. (1996). Translation of Ser16 and Thr17 phosphorylation of phospholamban into $\mathrm{Ca}^{2+}$-pump stimulation. Biochem. J. 316, 201-207. doi: 10.1042/bj3160201

Jalife, J., Anumonwo, J. M., and Berenfeld, O. (2003). Toward an understanding of the molecular mechanisms of ventricular fibrillation. J. Interv. Card. Electrophysiol. 9, 119-129. doi: 10.1023/A:1026215919730

Janssens, V., and Goris, J. (2001). Protein phosphatase 2A: a highly regulated family of serine/threonine phosphatases implicated in cell growth and signalling. Biochem. J. 353, 417-439. doi: 10.1042/bj3530417

Jeong, A. L., and Yang, Y. (2013). PP2A function toward mitotic kinases and substrates during the cell cycle. BMB Rep. 46, 289-294. doi: 10.5483/BMBRep.2013.46.6.041

Jespersen, T., Gavillet, B., Van Bemmelen, M. X., Cordonier, S., Thomas, M. A., Staub, O., et al. (2006). Cardiac sodium channel $\mathrm{Na}(\mathrm{v}) 1.5$ interacts with and is regulated by the protein tyrosine phosphatase PTPH1. Biochem. Biophys. Res. Commun. 348, 1455-1462. doi: 10.1016/j.bbrc.2006.08.014

Jessup, M., Fox, K. A., Komajda, M., Mcmurray, J. J., and Packer, M. (2014). PARADIGM-HF-the experts' discussion. N. Engl. J. Med. 371, e15. doi: 10.1056/NEJMp1410203

Jeyaraman, M., Tanguy, S., Fandrich, R. R., Lukas, A., and Kardami, E. (2003). Ischemia-induced dephosphorylation of cardiomyocyte connexin- 43 is reduced by okadaic acid and calyculin A but not fostriecin. Mol. Cell. Biochem. 242, 129-134. doi: 10.1023/A:1021102131603

Jideama, N. M., Crawford, B. H., Hussain, A. K., and Raynor, R. L. (2006). Dephosphorylation specificities of protein phosphatase for cardiac troponin I, troponin T, and sites within troponin T. Int. J. Biol. Sci. 2, 1-9. doi: $10.7150 /$ ijbs.2.1

Johnson, L. N. (2009). The regulation of protein phosphorylation. Biochem. Soc. Trans. 37, 627-641. doi: 10.1042/BST0370627 
Kamp, T. J., and Hell, J. W. (2000). Regulation of cardiac L-type calcium channels by protein kinase A and protein kinase C. Circ. Res. 87, 1095-1102. doi: 10.1161/01.RES.87.12.1095

Keen, J. C., Garrett-Mayer, E., Pettit, C., Mack, K. M., Manning, J., Herman, J. G., et al. (2004). Epigenetic regulation of protein phosphatase 2A (PP2A), lymphotactin (XCL1) and estrogen receptor (ER) expression in human breast cancer cells. Cancer Biol. Ther. 3, 1304-1312. doi: 10.4161/cbt.3.12.1458

Kimura, T., Han, W., Pagel, P., Nairn, A. C., and Caplan, M. J. (2011). Protein phosphatase $2 \mathrm{~A}$ interacts with the $\mathrm{Na}, \mathrm{K}$-ATPase and modulates its trafficking by inhibition of its association with arrestin. PLOS ONE 6:e29269. doi: 10.1371/journal.pone.0029269

Kirchner, J., Gross, S., Bennett, D., and Alphey, L. (2007). Essential, overlapping and redundant roles of the Drosophila protein phosphatase 1 and $1 \beta$ genes. Genetics 176, 273-281. doi: 10.1534/genetics.106.069914

Kolwicz, S. C. Jr., Purohit, S., and Tian, R. (2013). Cardiac metabolism and its interactions with contraction, growth, and survival of cardiomyocytes. Circ. Res. 113, 603-616. doi: 10.1161/CIRCRESAHA.113.302095

Korrodi-Gregorio, L., Esteves, S. L., and Fardilha, M. (2014). Protein phosphatase 1 catalytic isoforms: specificity toward interacting proteins. Transl. Res. 164, 366-391. doi: 10.1016/j.trsl.2014.07.001

Kreusser, M. M., and Backs, J. (2014). Integrated mechanisms of CaMKIIdependent ventricular remodeling. Front. Pharmacol. 5:36. doi: 10.3389/fphar.2014.00036

Kwon, Y. G., Huang, H. B., Desdouits, F., Girault, J. A., Greengard, P., and Nairn, A. C. (1997). Characterization of the interaction between DARPP-32 and protein phosphatase 1 (PP-1): DARPP-32 peptides antagonize the interaction of PP1 with binding proteins. Proc. Natl. Acad. Sci. U.S.A. 94, 3536-3541. doi: 10.1073/pnas.94.8.3536

Lauriol, J., Jaffre, F., and Kontaridis, M. I. (2015). The role of the protein tyrosine phosphatase SHP2 in cardiac development and disease. Semin. Cell Dev. Biol. 37, 73-81. doi: 10.1016/j.semcdb.2014.09.013

Lee, T. S., Karl, R., Moosmang, S., Lenhardt, P., Klugbauer, N., Hofmann, F., et al. (2006). Calmodulin kinase II is involved in voltage-dependent facilitation of the L-type Cav1.2 calcium channel: identification of the phosphorylation sites. J. Biol. Chem. 281, 25560-25567. doi: 10.1074/jbc.M508661200

Lei, M., Wang, X., Ke, Y., and Solaro, R. J. (2015). Regulation of $\mathrm{Ca}^{2+}$ transient by PP2A in normal and failing heart. Front Physiol 6:13. doi: 10.3389/fphys.2015.00013

Lemke, T., Welling, A., Christel, C. J., Blaich, A., Bernhard, D., Lenhardt, P., et al. (2008). Unchanged $\beta$-adrenergic stimulation of cardiac L-type calcium channels in Ca v 1.2 phosphorylation site S1928A mutant mice. J. Biol. Chem. 283, 34738-34744. doi: 10.1074/jbc.M804981200

Li, B., Kaetzel, M. A., and Dedman, J. R. (2006). Signaling pathways regulating murine cardiac CREB phosphorylation. Biochem. Biophys. Res. Commun. 350, 179-184. doi: 10.1016/j.bbrc.2006.09.016

Li, X., Wilmanns, M., Thornton, J., and Kohn, M. (2013). Elucidating human phosphatase-substrate networks. Sci. Signal. 6, rs10. doi: 10.1126/scisignal.2003203

Lim, H. W., and Molkentin, J. D. (1999). Calcineurin and human heart failure. Nat. Med. 5, 246-247. doi: 10.1038/6430

Ling, S., Sun, Q., Li, Y., Zhang, L., Zhang, P., Wang, X., et al. (2012). CKIP1 inhibits cardiac hypertrophy by regulating class II histone deacetylase phosphorylation through recruiting PP2A. Circulation 126, 3028-3040. doi: 10.1161/CIRCULATIONAHA.112.102780

Liu, B., Ho, H. T., Velez-Cortes, F., Lou, Q., Valdivia, C. R., Knollmann, B. C., et al. (2014). Genetic ablation of ryanodine receptor 2 phosphorylation at Ser-2808 aggravates $\mathrm{Ca}^{2+}$-dependent cardiomyopathy by exacerbating diastolic $\mathrm{Ca}^{2+}$ release. J. Physiol. 592, 1957-1973. doi: 10.1113/jphysiol.2013. 264689

Liu, C. L., Li, X., Hu, G. L., Li, R. J., He, Y. Y., Zhong, W., et al. (2012). Salubrinal protects against tunicamycin and hypoxia induced cardiomyocyte apoptosis via the PERK-eIF2 signaling pathway. J Geriatr. Cardiol. 9, 258-268. doi: 10.3724/SP.J.1263.2012.02292

Liu, C. W., Wang, R. H., Dohadwala, M., Schonthal, A. H., Villa-Moruzzi, E., and Berndt, N. (1999). Inhibitory phosphorylation of PP1 catalytic subunit during the G(1)/S transition. J. Biol. Chem. 274, 29470-29475. doi: $10.1074 /$ jbc. 274.41 .29470

Liu, J., Sirenko, S., Juhaszova, M., Ziman, B., Shetty, V., Rain, S., et al. (2011). A full range of mouse sinoatrial node AP firing rates requires protein kinase A-dependent calcium signaling. J. Mol. Cell Cardiol. 51, 730-739. doi: 10.1016/j.yjmcc.2011.07.028

Liu, R., Correll, R. N., Davis, J., Vagnozzi, R. J., York, A. J., Sargent, M. A., et al. (2015). Cardiac-specific deletion of protein phosphatase $1 \beta$ promotes increased myofilament protein phosphorylation and contractile alterations. J. Mol. Cell. Cardiol. 87, 204-213. doi: 10.1016/j.yjmcc.2015.08.018 [Epub ahead of print].

Liu, Y., and Schneider, M. F. (2013). Opposing HDAC4 nuclear fluxes due to phosphorylation by $\beta$-adrenergic activated protein kinase A or by activity or Epac activated CaMKII in skeletal muscle fibres. J. Physiol. 591, 3605-3623. doi: 10.1113/jphysiol.2013.256263

Luo, M., and Anderson, M. E. (2013). Mechanisms of altered $\mathrm{Ca}^{2+}$ handling in heart failure. Circ. Res. 113, 690-708. doi: 10.1161/CIRCRESAHA.113.301651

Luo, W., Grupp, I. L., Harrer, J., Ponniah, S., Grupp, G., Duffy, J. J., et al. (1994). Targeted ablation of the phospholamban gene is associated with markedly enhanced myocardial contractility and loss of $\beta$-agonist stimulation. Circ. Res. 75, 401-409. doi: 10.1161/01.RES.75.3.401

Luss, H., Klein-Wiele, O., Boknik, P., Herzig, S., Knapp, J., Linck, B., et al. (2000). Regional expression of protein phosphatase type 1 and 2A catalytic subunit isoforms in the human heart. J. Mol. Cell Cardiol. 32, 2349-2359. doi: $10.1006 /$ jmcc. 2000.1265

MacDougall, L. K., Jones, L. R., and Cohen, P. (1991). Identification of the major protein phosphatases in mammalian cardiac muscle which dephosphorylate phospholamban. Eur. J. Biochem. 196, 725-734. doi: 10.1111/j.1432-1033.1991.tb15871.x

Maillet, M., Purcell, N. H., Sargent, M. A., York, A. J., Bueno, O. F., and Molkentin, J. D. (2008). DUSP6 (MKP3) null mice show enhanced ERK1/2 phosphorylation at baseline and increased myocyte proliferation in the heart affecting disease susceptibility. J. Biol. Chem. 283, 31246-31255. doi: 10.1074/jbc.M806 085200

Marionneau, C., Lichti, C. F., Lindenbaum, P., Charpentier, F., Nerbonne, J. M., Townsend, R. R., et al. (2012). Mass spectrometry-based identification of native cardiac Nav1.5 channel subunit phosphorylation sites. J. Proteome Res. 11, 5994-6007. doi: 10.1021/pr300702c

Marks, A. R., Marx, S. O., and Reiken, S. (2002). Regulation of ryanodine receptors via macromolecular complexes: a novel role for leucine/isoleucine zippers. Trends Cardiovasc. Med. 12, 166-170. doi: 10.1016/S1050-1738(02)00156-1

Marx, S. O., Kurokawa, J., Reiken, S., Motoike, H., D’armiento, J., Marks, A. R., et al. (2002). Requirement of a macromolecular signaling complex for $\beta$ adrenergic receptor modulation of the KCNQ1-KCNE1 potassium channel. Science 295, 496-499. doi: 10.1126/science.1066843

Marx, S. O., Reiken, S., Hisamatsu, Y., Gaburjakova, M., Gaburjakova, J., Yang, Y. M., et al. (2001). Phosphorylation-dependent regulation of ryanodine receptors: a novel role for leucine/isoleucine zippers. J. Cell Biol. 153, 699-708. doi: 10.1083/jcb.153.4.699

Marx, S. O., Reiken, S., Hisamatsu, Y., Jayaraman, T., Burkhoff, D., Rosemblit, N., et al. (2000). PKA phosphorylation dissociates FKBP12.6 from the calcium release channel (ryanodine receptor): defective regulation in failing hearts. Cell 101, 365-376. doi: 10.1016/S0092-8674(00)80847-8

McAvoy, T., Allen, P. B., Obaishi, H., Nakanishi, H., Takai, Y., Greengard, P., et al. (1999). Regulation of neurabin I interaction with protein phosphatase 1 by phosphorylation. Biochemistry 38, 12943-12949. doi: 10.1021/bi991227d

McConnell, J. L., and Wadzinski, B. E. (2009). Targeting protein serine/threonine phosphatases for drug development. Mol. Pharmacol. 75, 1249-1261. doi: 10.1124/mol.108.053140

Meng, X., Xiao, B., Cai, S., Huang, X., Li, F., Bolstad, J., et al. (2007). Three-dimensional localization of serine 2808, a phosphorylation site in cardiac ryanodine receptor. J. Biol. Chem. 282, 25929-25939. doi: 10.1074/jbc.M704474200

Miller, C., Zhang, M., He, Y., Zhao, J., Pelletier, J. P., Martel-Pelletier, J., et al. (1998). Transcriptional induction of cyclooxygenase- 2 gene by okadaic acid inhibition of phosphatase activity in human chondrocytes: co-stimulation of AP-1 and CRE nuclear binding proteins. J. Cell. Biochem. 69, 392-413.

Minobe, E., Maeda, S., Xu, J., Hao, L., Kameyama, A., and Kameyama, M. (2014). A new phosphorylation site in cardiac L-type $\mathrm{Ca}^{2+}$ channels (Cav1.2) responsible for its cAMP-mediated modulation. Am. J. Physiol. Cell Physiol. 307, C999-C1009. doi: 10.1152/ajpcell.00267.2014

Mirtschink, P., Krishnan, J., Grimm, F., Sarre, A., Horl, M., Kayikci, M., et al. (2015). HIF-driven SF3B1 induces KHK-C to enforce fructolysis and heart disease. Nature 522, 444-449. doi: 10.1038/nature14508 
Mohamed, A. S., Dignam, J. D., and Schlender, K. K. (1998). Cardiac myosinbinding protein $\mathrm{C}$ (MyBP-C): identification of protein kinase $\mathrm{A}$ and protein kinase C phosphorylation sites. Arch. Biochem. Biophys. 358, 313-319. doi: 10.1006/abbi.1998.0857

Molkentin, J. D. (2000). Calcineurin and beyond: cardiac hypertrophic signaling. Circ. Res. 87, 731-738. doi: 10.1161/01.RES.87.9.731

Molkentin, J. D., Lu, J. R., Antos, C. L., Markham, B., Richardson, J., Robbins, J., et al. (1998). A calcineurin-dependent transcriptional pathway for cardiac hypertrophy. Cell 93, 215-228. doi: 10.1016/S0092-8674(00)81573-1

Montminy, M. R., Gonzalez, G. A., and Yamamoto, K. K. (1990). Characteristics of the cAMP response unit. Metabolism 39, 6-12. doi: 10.1016/00260495(90)90198-L

Moorhead, G. B., Trinkle-Mulcahy, L., and Ulke-Lemee, A. (2007). Emerging roles of nuclear protein phosphatases. Nat. Rev. Mol. Cell Biol. 8, 234-244. doi: $10.1038 / \mathrm{nrm} 2126$

Murnion, M. E., Adams, R. R., Callister, D. M., Allis, C. D., Earnshaw, W. C., and Swedlow, J. R. (2001). Chromatin-associated protein phosphatase 1 regulates aurora-B and histone H3 phosphorylation. J. Biol. Chem. 276, 26656-26665. doi: 10.1074/jbc.M102288200

Murray, K. T., Hu, N. N., Daw, J. R., Shin, H. G., Watson, M. T., Mashburn, A. B., et al. (1997). Functional effects of protein kinase $C$ activation on the human cardiac $\mathrm{Na}^{+}$channel. Circ. Res. 80, 370-376. doi: 10.1161/01.RES.80.3.370

Narayanan, N., and Xu, A. (1997). Phosphorylation and regulation of the $\mathrm{Ca}^{2+}$ pumping ATPase in cardiac sarcoplasmic reticulum by calcium/calmodulindependent protein kinase. Basic Res. Cardiol. 92(Suppl. 1), 25-35. doi: 10.1007/BF00794065

Nattel, S., Burstein, B., and Dobrev, D. (2008). Atrial remodeling and atrial fibrillation: mechanisms and implications. Circ. Arrhythm. Electrophysiol. 1, 62-73. doi: 10.1161/CIRCEP.107.754564

Neef, S., Dybkova, N., Sossalla, S., Ort, K. R., Fluschnik, N., Neumann, K., et al. (2010). CaMKII-dependent diastolic SR $\mathrm{Ca}^{2+}$ leak and elevated diastolic $\mathrm{Ca}^{2+}$ levels in right atrial myocardium of patients with atrial fibrillation. Circ. Res. 106, 1134-1144. doi: 10.1161/CIRCRESAHA.109.203836

Neuber, C., Uebeler, J., Schulze, T., Sotoud, H., El-Armouche, A., and Eschenhagen, T. (2014). Guanabenz interferes with ER stress and exerts protective effects in cardiac myocytes. PLoS ONE 9:e98893. doi: 10.1371/journal.pone.0098893

Neumann, J., Eschenhagen, T., Jones, L. R., Linck, B., Schmitz, W., Scholz, H., et al. (1997). Increased expression of cardiac phosphatases in patients with end-stage heart failure. J. Mol. Cell Cardiol. 29, 265-272. doi: 10.1006/jmcc.1996.0271

Neumann, J., Maas, R., Boknik, P., Jones, L. R., Zimmermann, N., and Scholz, H. (1999). Pharmacological characterization of protein phosphatase activities in preparations from failing human hearts. J. Pharmacol. Exp. Ther. 289, 188-193.

Nicolaou, P., Hajjar, R. J., and Kranias, E. G. (2009). Role of protein phosphatase-1 inhibitor-1 in cardiac physiology and pathophysiology. J. Mol. Cell Cardiol. 47, 365-371. doi: 10.1016/j.yjmcc.2009.05.010

Nicolas, C. S., Park, K. H., El Harchi, A., Camonis, J., Kass, R. S., Escande, D., et al. (2008). IKs response to protein kinase A-dependent KCNQ1 phosphorylation requires direct interaction with microtubules. Cardiovasc. Res. 79, 427-435. doi: $10.1093 / \mathrm{cvr} / \mathrm{cvn} 085$

Nikandrova, Y. A., Jiao, Y., Baucum, A. J., Tavalin, S. J., and Colbran, R. J. (2010). $\mathrm{Ca}^{2+} /$ calmodulin-dependent protein kinase II binds to and phosphorylates a specific SAP97 splice variant to disrupt association with AKAP79/150 and modulate -amino-3-hydroxy-5-methyl-4-isoxazolepropionic acid-type glutamate receptor (AMPAR) activity. J. Biol. Chem. 285, 923-934. doi: 10.1074/jbc.M109.033985

Novak, B., Kapuy, O., Domingo-Sananes, M. R., and Tyson, J. J. (2010). Regulated protein kinases and phosphatases in cell cycle decisions. Curr. Opin. Cell Biol. 22, 801-808. doi: 10.1016/j.ceb.2010.07.001

Okamura, H., Garcia-Rodriguez, C., Martinson, H., Qin, J., Virshup, D. M., and Rao, A. (2004). A conserved docking motif for CK1 binding controls the nuclear localization of NFAT1. Mol. Cell. Biol. 24, 4184-4195. doi: 10.1128/MCB.24.10.4184-4195.2004

Oka, T., Dai, Y. S., and Molkentin, J. D. (2005). Regulation of calcineurin through transcriptional induction of the calcineurin $\mathrm{A} \beta$ promoter in vitro and in vivo. Mol. Cell. Biol. 25, 6649-6659. doi: 10.1128/MCB.25.15.6649-6659.2005

Oliver, C. J., Terry-Lorenzo, R. T., Elliott, E., Bloomer, W. A., Li, S., Brautigan, D. L., et al. (2002). Targeting protein phosphatase 1 (PP1) to the actin cytoskeleton: the neurabin I/PP1 complex regulates cell morphology. Mol. Cell. Biol. 22, 4690-4701. doi: 10.1128/MCB.22.13.4690-4701.2002
Olsen, J. V., Blagoev, B., Gnad, F., Macek, B., Kumar, C., Mortensen, P., et al. (2006). Global, in vivo, and site-specific phosphorylation dynamics in signaling networks. Cell 127, 635-648. doi: 10.1016/j.cell.2006.09.026

Otmakhov, N., Regmi, S., and Lisman, J. E. (2015). Fast decay of CaMKII FRET sensor signal in spines after LTP induction is not due to its dephosphorylation. PLoS ONE 10:e0130457. doi: 10.1371/journal.pone.0130457

Packer, M. (1985). Sudden unexpected death in patients with congestive heart failure: a second frontier. Circulation 72, 681-685. doi: 10.1161/01.CIR.7 2.4 .681

Palmer, C. J., Scott, B. T., and Jones, L. R. (1991). Purification and complete sequence determination of the major plasma membrane substrate for cAMPdependent protein kinase and protein kinase $\mathrm{C}$ in myocardium. J. Biol. Chem. 266, 11126-11130.

Palmeri, A., Ferre, F., and Helmer-Citterich, M. (2014). Exploiting holistic approaches to model specificity in protein phosphorylation. Front. Genet. 5:315. doi: $10.3389 /$ fgene. 2014.00315

Pan, M. G., Xiong, Y., and Chen, F. (2013). NFAT gene family in inflammation and cancer. Curr. Mol. Med. 13, 543-554. doi: 10.2174/1566524011313040007

Pare, G. C., Bauman, A. L., Mchenry, M., Michel, J. J., Dodge-Kafka, K. L., and Kapiloff, M. S. (2005). The mAKAP complex participates in the induction of cardiac myocyte hypertrophy by adrenergic receptor signaling. J. Cell Sci. 118, 5637-5646. doi: 10.1242/jcs.02675

Paroni, G., Cernotta, N., Dello Russo, C., Gallinari, P., Pallaoro, M., Foti, C., et al. (2008). PP2A regulates HDAC4 nuclear import. Mol. Biol. Cell 19, 655-667. doi: 10.1091/mbc.E07-06-0623

Pathak, A., Del Monte, F., Zhao, W., Schultz, J. E., Lorenz, J. N., Bodi, I., et al. (2005). Enhancement of cardiac function and suppression of heart failure progression by inhibition of protein phosphatase 1. Circ. Res. 96, 756-766. doi: 10.1161/01.RES.0000161256.85833.fa

Patterson, K. I., Brummer, T., O’brien, P. M., and Daly, R. J. (2009). Dual-specificity phosphatases: critical regulators with diverse cellular targets. Biochem. J. 418, 475-489. doi: 10.1042/BJ20082234

Peti, W., Nairn, A. C., and Page, R. (2013). Structural basis for protein phosphatase 1 regulation and specificity. FEBS J. 280, 596-611. doi: 10.1111/j.17424658.2012.08509. $\mathrm{x}$

Petzhold, D., Da Costa-Goncalves, A. C., Gross, V., and Morano, I. (2011). Spinophilin is required for normal morphology, $\mathrm{Ca}^{2+}$ homeostasis and contraction but dispensable for $\beta$-adrenergic stimulation of adult cardiomyocytes. J. Muscle Res. Cell Motil. 32, 243-248. doi: 10.1007/s10974-011-9259-4

Prystowsky, E. N., Padanilam, B. J., Joshi, S., and Fogel, R. I. (2012). Ventricular arrhythmias in the absence of structural heart disease. J. Am. Coll. Cardiol. 59, 1733-1744. doi: 10.1016/j.jacc.2012.01.036

Pulido, R., and Hooft van Huijsduijnen, R. (2008). Protein tyrosine phosphatases: dual-specificity phosphatases in health and disease. FEBS J. 275, 848-866. doi: 10.1111/j.1742-4658.2008.06250.x

Qu, Z., and Weiss, J. N. (2015). Mechanisms of ventricular arrhythmias: from molecular fluctuations to electrical turbulence. Annu. Rev. Physiol. 77, 29-55. doi: 10.1146/annurev-physiol-021014-071622

Raghavan, S., Williams, I., Aslam, H., Thomas, D., Szoor, B., Morgan, G., et al. (2000). Protein phosphatase $1 \beta$ is required for the maintenance of muscle attachments. Curr. Biol. 10, 269-272. doi: 10.1016/S0960-9822(00)00364-X

Ragusa, M. J., Allaire, M., Nairn, A. C., Page, R., and Peti, W. (2011). Flexibility in the PP1:spinophilin holoenzyme. FEBS Lett. 585, 36-40. doi: 10.1016/j.febslet.2010.11.022

Ragusa, M. J., Dancheck, B., Critton, D. A., Nairn, A. C., Page, R., and Peti, W. (2010). Spinophilin directs protein phosphatase 1 specificity by blocking substrate binding sites. Nat. Struct. Mol. Biol. 17, 459-464. doi: 10.1038/nsmb.1786

Rapundalo, S. T. (1998). Cardiac protein phosphorylation: functional and pathophysiological correlates. Cardiovasc. Res. 38, 559-588. doi: 10.1016/S00086363(98)00063-7

Redden, J. M., and Dodge-Kafka, K. L. (2011). AKAP phosphatase complexes in the heart. J. Cardiovasc. Pharmacol. 58, 354-362. doi: 10.1097/FJC.0b013e31821e5649

Reese, L. C., Laezza, F., Woltjer, R., and Taglialatela, G. (2011). Dysregulated phosphorylation of $\mathrm{Ca}^{2+} /$ calmodulin-dependent protein kinase II- in the hippocampus of subjects with mild cognitive impairment and Alzheimer's disease. J. Neurochem. 119, 791-804. doi: 10.1111/j.1471-4159.2011.07447.x 
Reiken, S., Gaburjakova, M., Guatimosim, S., Gomez, A. M., D’armiento, J., Burkhoff, D., et al. (2003). Protein kinase A phosphorylation of the cardiac calcium release channel (ryanodine receptor) in normal and failing hearts. Role of phosphatases and response to isoproterenol. J. Biol. Chem. 278, 444-453. doi: 10.1074/jbc.M207028200

Reither, G., Chatterjee, J., Beullens, M., Bollen, M., Schultz, C., and Kohn, M. (2013). Chemical activators of protein phosphatase-1 induce calcium release inside intact cells. Chem. Biol. 20, 1179-1186. doi: 10.1016/j.chembiol.2013.07.008

Remo, B. F., Giovannone, S., and Fishman, G. I. (2012). Connexin43 cardiac gap junction remodeling: lessons from genetically engineered murine models. $J$. Membr. Biol. 245, 275-281. doi: 10.1007/s00232-012-9448-0

Roberts-Thomson, K. C., Lau, D. H., and Sanders, P. (2011). The diagnosis and management of ventricular arrhythmias. Nat. Rev. Cardiol. 8, 311-321. doi: 10.1038/nrcardio. 2011.15

Roskoski, R. Jr. (2015). A historical overview of protein kinases and their targeted small molecule inhibitors. Pharmacol. Res. 100, 1-23. doi: 10.1016/j.phrs.2015.07.010

Rossow, C. F., Dilly, K. W., and Santana, L. F. (2006). Differential calcineurin/NFATc3 activity contributes to the ito transmural gradient in the mouse heart. Circ. Res. 98, 1306-1313. doi: 10.1161/01.RES.0000222028.92993.10

Rossow, C. F., Minami, E., Chase, E. G., Murry, C. E., and Santana, L. F. (2004). NFATc3-induced reductions in voltage-gated $\mathrm{K}^{+}$currents after myocardial infarction. Circ. Res. 94, 1340-1350. doi: 10.1161/01.RES.0000128406.08418.34

Roy, J., and Cyert, M. S. (2009). Cracking the phosphatase code: docking interactions determine substrate specificity. Sci. Signal. 2, re9. doi: 10.1126/scisignal.2100re9

Sakisaka, T., Nakanishi, H., Takahashi, K., Mandai, K., Miyahara, M., Satoh, A., et al. (1999). Different behavior of 1 -afadin and neurabin-II during the formation and destruction of cell-cell adherens junction. Oncogene 18, 1609-1617. doi: 10.1038/sj.onc. 1202451

Sato, P. Y., Chuprun, J. K., Schwartz, M., and Koch, W. J. (2015). The evolving impact of g protein-coupled receptor kinases in cardiac health and disease. Physiol. Rev. 95, 377-404. doi: 10.1152/physrev.00015.2014

Sawicka, A., and Seiser, C. (2014). Sensing core histone phosphorylation-a matter of perfect timing. Biochim. Biophys. Acta 1839, 711-718. doi: 10.1016/j.bbagrm.2014.04.013

Schillinger, W., Fiolet, J. W., Schlotthauer, K., and Hasenfuss, G. (2003). Relevance of $\mathrm{Na}^{+}-\mathrm{Ca}^{2+}$ exchange in heart failure. Cardiovasc. Res. 57, 921-933. doi: 10.1016/S0008-6363(02)00826-X

Schulze, D. H., Muqhal, M., Lederer, W. J., and Ruknudin, A. M. (2003). Sodium/calcium exchanger (NCX1) macromolecular complex. J. Biol. Chem. 278, 28849-28855. doi: 10.1074/jbc.M300754200

Schwinger, R. H., Bundgaard, H., Muller-Ehmsen, J., and Kjeldsen, K. (2003). The $\mathrm{Na}, \mathrm{K}-\mathrm{ATP}$ ase in the failing human heart. Cardiovasc. Res. 57, 913-920. doi: 10.1016/S0008-6363(02)00767-8

Schwoerer, A. P., Neuber, C., Schmechel, A., Melnychenko, I., Mearini, G., Boknik, P., et al. (2008). Mechanical unloading of the rat heart involves marked changes in the protein kinase-phosphatase balance. J. Mol. Cell Cardiol. 45, 846-852. doi: 10.1016/j.yjmcc.2008.09.003

Sears, D., Luong, P., Yuan, M., Nteliopoulos, G., Man, Y. K., Melo, J. V., et al. (2010). Functional phosphoproteomic analysis reveals cold-shock domain protein A to be a Bcr-Abl effector-regulating proliferation and transformation in chronic myeloid leukemia. Cell Death Dis. 1, e93. doi: 10.1038/cddis.2010.72

Sefton, B. M. (2001). Overview of protein phosphorylation. Curr. Protoc. Cell Biol. 14. doi: 10.1002/0471143030.cb1401s00

Senis, Y. A. (2013). Protein-tyrosine phosphatases: a new frontier in platelet signal transduction. J. Thromb. Haemost. 11, 1800-1813. doi: 10.1111/jth.12359

Sheridan, C. M., Heist, E. K., Beals, C. R., Crabtree, G. R., and Gardner, P. (2002). Protein kinase A negatively modulates the nuclear accumulation of NF-ATc1 by priming for subsequent phosphorylation by glycogen synthase kinase-3. J. Biol. Chem. 277, 48664-48676. doi: 10.1074/jbc.M207029200

Shi, J., Gu, P., Zhu, Z., Liu, J., Chen, Z., Sun, X., et al. (2012). Protein phosphatase 2A effectively modulates basal L-type $\mathrm{Ca}^{2+}$ current by dephosphorylating $\mathrm{Ca}(\mathrm{v}) 1.2$ at serine 1866 in mouse cardiac myocytes. Biochem. Biophys. Res. Commun. 418, 792-798. doi: 10.1016/j.bbrc.2012.01.105

Shigekawa, M., Katanosaka, Y., and Wakabayashi, S. (2007). Regulation of the cardiac $\mathrm{Na}^{+} / \mathrm{Ca}^{2+}$ exchanger by calcineurin and protein kinase C. Ann. N. Y. Acad. Sci. 1099, 53-63. doi: 10.1196/annals.1387.059
Singh, A., Redden, J. M., Kapiloff, M. S., and Dodge-Kafka, K. L. (2011). The large isoforms of A-kinase anchoring protein 18 mediate the phosphorylation of inhibitor-1 by protein kinase A and the inhibition of protein phosphatase 1 activity. Mol. Pharmacol. 79, 533-540. doi: 10.1124/mol.110.065425

Sipido, K. R., Bito, V., Antoons, G., Volders, P. G., and Vos, M. A. (2007). Na/Ca exchange and cardiac ventricular arrhythmias. Ann. N. Y. Acad. Sci. 1099, 339-348. doi: 10.1196/annals.1387.066

Slupe, A. M., Merrill, R. A., and Strack, S. (2011). Determinants for substrate specificity of protein phosphatase 2A. Enzyme Res. 2011, 398751. doi: $10.4061 / 2011 / 398751$

Solaro, R. J., and Kobayashi, T. (2011). Protein phosphorylation and signal transduction in cardiac thin filaments. J. Biol. Chem. 286, 9935-9940. doi: 10.1074/jbc.R110.197731

Solomon, S. D., Zile, M., Pieske, B., Voors, A., Shah, A., Kraigher-Krainer, E., et al. (2012). The angiotensin receptor neprilysin inhibitor LCZ696 in heart failure with preserved ejection fraction: a phase 2 double-blind randomised controlled trial. Lancet 380, 1387-1395. doi: 10.1016/S0140-6736(12)61227-6

Sonnleitner, A., Fleischer, S., and Schindler, H. (1997). Gating of the skeletal calcium release channel by ATP is inhibited by protein phosphatase 1 but not by $\mathrm{Mg}^{2+}$. Cell Calcium 21, 283-290. doi: 10.1016/S0143-4160(97)90116-0

Sotoud, H., Borgmeyer, U., Schulze, C., El-Armouche, A., and Eschenhagen, T. (2015). Development of phosphatase inhibitor-1 peptides acting as indirect activators of phosphatase 1. Naunyn Schmiedebergs Arch. Pharmacol. 388, 283-293. doi: 10.1007/s00210-014-1065-2

Splawski, I., Timothy, K. W., Sharpe, L. M., Decher, N., Kumar, P., Bloise, R., et al. (2004). Ca(V)1.2 calcium channel dysfunction causes a multisystem disorder including arrhythmia and autism. Cell 119, 19-31. doi: 10.1016/j.cell.2004.09.011

Sumandea, M. P., and Steinberg, S. F. (2011). Redox signaling and cardiac sarcomeres. J. Biol. Chem. 286, 9921-9927. doi: 10.1074/jbc.R110.175489

Sun, H., Kerfant, B. G., Zhao, D., Trivieri, M. G., Oudit, G. Y., Penninger, J. M., et al. (2006). Insulin-like growth factor-1 and PTEN deletion enhance cardiac L-type $\mathrm{Ca}^{2+}$ currents via increased PI3K/PKB signaling. Circ. Res. 98, 1390-1397. doi: 10.1161/01.RES.0000223321.34482.8c

Tajada, S., Cidad, P., Colinas, O., Santana, L. F., Lopez-Lopez, J. R., and PerezGarcia, M. T. (2013). Down-regulation of CaV1.2 channels during hypertension: how fewer CaV1.2 channels allow more $\mathrm{Ca}^{2+}$ into hypertensive arterial smooth muscle. J. Physiol. 591, 6175-6191. doi: 10.1113/jphysiol.2013.265751

Tandan, S., Wang, Y., Wang, T. T., Jiang, N., Hall, D. D., Hell, J. W., et al. (2009). Physical and functional interaction between calcineurin and the cardiac L-type $\mathrm{Ca}^{2+}$ channel. Circ. Res. 105, 51-60. doi: 10.1161/CIRCRESAHA.109.199828

Tang, Z. Z., Liao, P., Li, G., Jiang, F. L., Yu, D., Hong, X., et al. (2008). Differential splicing patterns of L-type calcium channel Cav1.2 subunit in hearts of Spontaneously Hypertensive Rats and Wistar Kyoto Rats. Biochim. Biophys. Acta 1783, 118-130. doi: 10.1016/j.bbamcr.2007.11.003

Terrak, M., Kerff, F., Langsetmo, K., Tao, T., and Dominguez, R. (2004). Structural basis of protein phosphatase 1 regulation. Nature 429, 780-784. doi: 10.1038 /nature 02582

Terrenoire, C., Houslay, M. D., Baillie, G. S., and Kass, R. S. (2009). The cardiac IKs potassium channel macromolecular complex includes the phosphodiesterase PDE4D3. J. Biol. Chem. 284, 9140-9146. doi: 10.1074/jbc.M805366200

Toischer, K., Hartmann, N., Wagner, S., Fischer, T. H., Herting, J., Danner, B. C., et al. (2013). Role of late sodium current as a potential arrhythmogenic mechanism in the progression of pressure-induced heart disease. J. Mol. Cell Cardiol. 61, 111-122. doi: 10.1016/j.yjmcc.2013.03.021

Trinkle-Mulcahy, L., Andersen, J., Lam, Y. W., Moorhead, G., Mann, M., and Lamond, A. I. (2006). Repo-Man recruits PP1 $\gamma$ to chromatin and is essential for cell viability. J. Cell Biol. 172, 679-692. doi: 10.1083/jcb.200508154

Tsaytler, P., Harding, H. P., Ron, D., and Bertolotti, A. (2011). Selective inhibition of a regulatory subunit of protein phosphatase 1 restores proteostasis. Science 332, 91-94. doi: 10.1126/science.1201396

Ubersax, J. A., and Ferrell, J. E. Jr. (2007). Mechanisms of specificity in protein phosphorylation. Nat. Rev. Mol. Cell Biol. 8, 530-541. doi: 10.1038/nrm2203

Ucar, A., Gupta, S. K., Fiedler, J., Erikci, E., Kardasinski, M., Batkai, S., et al. (2012). The miRNA-212/132 family regulates both cardiac hypertrophy and cardiomyocyte autophagy. Nat. Commun. 3, 1078. doi: 10.1038/ncomms2090

Uehata, M., Ishizaki, T., Satoh, H., Ono, T., Kawahara, T., Morishita, T., et al. (1997). Calcium sensitization of smooth muscle mediated by a Rho-associated protein kinase in hypertension. Nature 389, 990-994. doi: 10.1038/40187 
Vermeulen, J. T., Mcguire, M. A., Opthof, T., Coronel, R., De Bakker, J. M., Klopping, C., et al. (1994). Triggered activity and automaticity in ventricular trabeculae of failing human and rabbit hearts. Cardiovasc. Res. 28, 1547-1554. doi: $10.1093 / \mathrm{cvr} / 28.10 .1547$

von Holtey, M., Csermely, P., Niggemann, J., and Eckel, J. (1996). Insulininduced phosphorylation of a $38 \mathrm{kDa}$ DNA-binding protein in ventricular cardiomyocytes: possible implication of nuclear protein phosphatase activity. Mol. Cell. Endocrinol. 120, 107-114. doi: 10.1016/0303-7207(96)03828-2

Wagner, S., Dybkova, N., Rasenack, E. C., Jacobshagen, C., Fabritz, L., Kirchhof, P., et al. (2006). $\mathrm{Ca}^{2+} /$ calmodulin-dependent protein kinase II regulates cardiac $\mathrm{Na}^{+}$channels. J. Clin. Invest. 116, 3127-3138. doi: 10.1172/JCI26620

Walker, K. S., Watt, P. W., and Cohen, P. (2000). Phosphorylation of the skeletal muscle glycogen-targetting subunit of protein phosphatase 1 in response to adrenaline in vivo. FEBS Lett. 466, 121-124. doi: 10.1016/S0014-5793(99) 01771-8

Wang, R. H., Liu, C. W., Avramis, V. I., and Berndt, N. (2001). Protein phosphatase 1-mediated stimulation of apoptosis is associated with dephosphorylation of the retinoblastoma protein. Oncogene 20, 6111-6122. doi: 10.1038/sj.onc.1204829

Wang, Y., Tandan, S., and Hill, J. A. (2014). Calcineurin-dependent ion channel regulation in heart. Trends. Cardiovasc. Med. 24, 14-22. doi: 10.1016/j.tcm.2013.05.004

Wanichawan, P., Louch, W. E., Hortemo, K. H., Austbo, B., Lunde, P. K., Scott, J. D., et al. (2011). Full-length cardiac $\mathrm{Na}^{+} / \mathrm{Ca}^{2+}$ exchanger 1 protein is not phosphorylated by protein kinase A. Am. J. Physiol. Cell Physiol. 300, C989-C997. doi: 10.1152/ajpcell.00196.2010

Wei, S. K., Ruknudin, A., Hanlon, S. U., Mccurley, J. M., Schulze, D. H., and Haigney, M. C. (2003). Protein kinase A hyperphosphorylation increases basal current but decreases $\beta$-adrenergic responsiveness of the sarcolemmal $\mathrm{Na}^{+}-\mathrm{Ca}^{2+}$ exchanger in failing pig myocytes. Circ. Res. 92, 897-903. doi: 10.1161/01.RES.0000069701.19660.14

Wei, S. K., Ruknudin, A. M., Shou, M., Mccurley, J. M., Hanlon, S. U., Elgin, E., et al. (2007). Muscarinic modulation of the sodium-calcium exchanger in heart failure. Circulation 115, 1225-1233. doi: 10.1161/circulationaha.106.650416

Weiss, J. N., Chen, P. S., Qu, Z., Karagueuzian, H. S., and Garfinkel, A. (2000). Ventricular fibrillation: how do we stop the waves from breaking? Circ. Res. 87, 1103-1107. doi: 10.1161/01.res.87.12.1103

Westphal, R. S., Tavalin, S. J., Lin, J. W., Alto, N. M., Fraser, I. D., Langeberg, L. K., et al. (1999). Regulation of NMDA receptors by an associated phosphatasekinase signaling complex. Science 285, 93-96. doi: 10.1126/science.285. 5424.93

Wilkins, B. J., Dai, Y. S., Bueno, O. F., Parsons, S. A., Xu, J., Plank, D. M., et al. (2004). Calcineurin/NFAT coupling participates in pathological, but not physiological, cardiac hypertrophy. Circ. Res. 94, 110-118. doi: 10.1161/01.RES.0000109415.17511.18

Wittkopper, K., Dobrev, D., Eschenhagen, T., and El-Armouche, A. (2011). Phosphatase-1 inhibitor- 1 in physiological and pathological $\beta$-adrenoceptor signalling. Cardiovasc. Res. 91, 392-401. doi: 10.1093/cvr/cvr058

Wittkopper, K., Eschenhagen, T., and El-Armouche, A. (2010a). Phosphatase1-inhibitor-1: amplifier or attenuator of catecholaminergic stress? Basic Res. Cardiol. 105, 569-571. doi: 10.1007/s00395-010-0107-2

Wittkopper, K., Fabritz, L., Neef, S., Ort, K. R., Grefe, C., Unsold, B., et al. (2010b). Constitutively active phosphatase inhibitor-1 improves cardiac contractility in young mice but is deleterious after catecholaminergic stress and with aging. J. Clin. Invest. 120, 617-626. doi: 10.1172/jci40545

Wolska, B. M. (2009). Calcineurin and cardiac function: is more or less better for the heart? Am. J. Physiol. Heart Circ. Physiol. 297, H1576-H1577. doi: 10.1152/ajpheart.00833.2009

Woodgett, J. R., and Cohen, P. (1984). Multisite phosphorylation of glycogen synthase. Molecular basis for the substrate specificity of glycogen synthase kinase- 3 and casein kinase-II (glycogen synthase kinase-5). Biochim. Biophys. Acta 788, 339-347. doi: 10.1016/0167-4838(84)90047-5

Xiao, B., Jiang, M. T., Zhao, M., Yang, D., Sutherland, C., Lai, F. A., et al. (2005). Characterization of a novel PKA phosphorylation site, serine-2030, reveals no PKA hyperphosphorylation of the cardiac ryanodine receptor in canine heart failure. Circ. Res. 96, 847-855. doi: 10.1161/01.RES.0000163276.26083.e8

Xiao, B., Zhong, G., Obayashi, M., Yang, D., Chen, K., Walsh, M. P., et al. (2006). Ser-2030, but not Ser-2808, is the major phosphorylation site in cardiac ryanodine receptors responding to protein kinase A activation upon $\beta$ adrenergic stimulation in normal and failing hearts. Biochem. J. 396, 7-16. doi: 10.1042/BJ20060116

Xu, H., Ginsburg, K. S., Hall, D. D., Zimmermann, M., Stein, I. S., Zhang, M., et al. (2010). Targeting of protein phosphatases PP2A and PP2B to the C-terminus of the L-type calcium channel Ca v1.2. Biochemistry 49, 10298-10307. doi: 10.1021/bi101018c

Yamakita, Y., Totsukawa, G., Yamashiro, S., Fry, D., Zhang, X., Hanks, S. K., et al. (1999). Dissociation of FAK/p130(CAS)/c-Src complex during mitosis: role of mitosis-specific serine phosphorylation of FAK. J. Cell Biol. 144, 315-324. doi: 10.1083/jcb.144.2.315

Yang, L., Liu, G., Zakharov, S. I., Bellinger, A. M., Mongillo, M., and Marx, S. O. (2007). Protein kinase G phosphorylates Cav1.2 1c and $\beta 2$ subunits. Circ. Res. 101, 465-474. doi: 10.1161/CIRCRESAHA.107.156976

Yang, L., Liu, G., Zakharov, S. I., Morrow, J. P., Rybin, V. O., Steinberg, S. F., et al. (2005). Ser1928 is a common site for Cav1.2 phosphorylation by protein kinase C isoforms. J. Biol. Chem. 280, 207-214. doi: 10.1074/jbc.M410509200

Yang, T. T., Xiong, Q., Enslen, H., Davis, R. J., and Chow, C. W. (2002). Phosphorylation of NFATc4 by p38 mitogen-activated protein kinases. Mol. Cell. Biol. 22, 3892-3904. doi: 10.1128/MCB.22.11.3892-3904.2002

Yger, M., and Girault, J. A. (2011). DARPP-32, Jack of All Trades... Master of Which? Front. Behav. Neurosci. 5:56. doi: 10.3389/fnbeh.2011.00056

Yin, X., Cuello, F., Mayr, U., Hao, Z., Hornshaw, M., Ehler, E., et al. (2010). Proteomics analysis of the cardiac myofilament subproteome reveals dynamic alterations in phosphatase subunit distribution. Mol. Cell. Proteomics 9, 497-509. doi: 10.1074/mcp.M900275-MCP200

Zhang, C. L., Mckinsey, T. A., Chang, S., Antos, C. L., Hill, J. A., and Olson, E. N. (2002). Class II histone deacetylases act as signal-responsive repressors of cardiac hypertrophy. Cell 110, 479-488. doi: 10.1016/S0092-8674(02)00861-9

Zhang, H., Makarewich, C. A., Kubo, H., Wang, W., Duran, J. M., Li, Y., et al. (2012). Hyperphosphorylation of the cardiac ryanodine receptor at serine 2808 is not involved in cardiac dysfunction after myocardial infarction. Circ. Res. 110, 831-840. doi: 10.1161/CIRCRESAHA.111.255158

Zhang, Y. H., and Hancox, J. C. (2009). Regulation of cardiac $\mathrm{Na}^{+}-\mathrm{Ca}^{2+}$ exchanger activity by protein kinase phosphorylation-still a paradox? Cell Calcium 45, 1-10. doi: 10.1016/j.ceca.2008.05.005

Zhou, J., Yi, J., Hu, N., George, A. L. Jr., and Murray, K. T. (2000). Activation of protein kinase A modulates trafficking of the human cardiac sodium channel in Xenopus oocytes. Circ. Res. 87, 33-38. doi: 10.1161/01.RES.87.1.33

Zhu, G., Liu, Y., and Shaw, S. (2005). Protein kinase specificity. A strategic collaboration between kinase peptide specificity and substrate recruitment. Cell Cycle 4, 52-56. doi: 10.4161/cc.4.1.1353

Zhu, J., Shibasaki, F., Price, R., Guillemot, J. C., Yano, T., Dotsch, V., et al. (1998). Intramolecular masking of nuclear import signal on NF-AT4 by casein kinase I and MEKK1. Cell 93, 851-861. doi: 10.1016/S0092-8674(00)81445-2

Zou, Y., Liang, Y., Gong, H., Zhou, N., Ma, H., Guan, A., et al. (2011). Ryanodine receptor type 2 is required for the development of pressure overload-induced cardiac hypertrophy. Hypertension 58, 1099-1110. doi: 10.1161/HYPERTENSIONAHA.111.173500

Zylinska, L., Guerini, D., Gromadzinska, E., and Lachowicz, L. (1998). Protein kinases $\mathrm{A}$ and $\mathrm{C}$ phosphorylate purified $\mathrm{Ca}^{2+}$-ATPase from rat cortex, cerebellum and hippocampus. Biochim. Biophys. Acta 1448, 99-108. doi: 10.1016/S0167-4889(98)00128-1

Zylinska, L., and Soszynski, M. (2000). Plasma membrane $\mathrm{Ca}^{2+}$-ATPase in excitable and nonexcitable cells. Acta Biochim. Pol. 47, 529-539.

Conflict of Interest Statement: The authors declare that the research was conducted in the absence of any commercial or financial relationships that could be construed as a potential conflict of interest.

Copyright (c) 2015 Weber, Meyer-Roxlau, Wagner, Dobrev and El-Armouche. This is an open-access article distributed under the terms of the Creative Commons Attribution License (CC BY). The use, distribution or reproduction in other forums is permitted, provided the original author(s) or licensor are credited and that the original publication in this journal is cited, in accordance with accepted academic practice. No use, distribution or reproduction is permitted which does not comply with these terms. 